\title{
Autonomous methane seep site monitoring offshore Western Svalbard: Hourly to seasonal variability and associated oceanographic parameters
}

\author{
Knut Ola Dølven ${ }^{1}$, Bénédicte Ferré ${ }^{1}$, Anna Silyakova ${ }^{1}$, Pär Jansson ${ }^{2, *}$, Peter Linke $^{3, *}$, and \\ Manuel Moser ${ }^{1 *}$ \\ ${ }^{1}$ Centre for Arctic Gas Hydrate, Environment, and Climate,UiT The Arctic University of Norway, 9019 Troms $\varnothing$, Norway \\ ${ }^{2}$ Multiconsult Kyst og Marin, 9013 Troms $\varnothing$, Norway \\ ${ }^{3}$ GEOMAR Helmholtz Centre for Ocean Research Kiel, 24148 Kiel, Germany \\ *These authors contributed equally to this work
}

Correspondence: Knut Ola Dølven (knut.o.dolven@uit.no)

\begin{abstract}
Improved quantification techniques of natural sources is needed to explain variations in atmospheric methane. In polar regions, high uncertainties in current estimates of methane release from the seabed remain. We present two unique 10 and 3 months long time-series of bottom water measurements of physical and chemical parameters from two autonomous ocean observatories deployed at separate intense seabed methane seep sites (91 and 246m depth), offshore Western Svalbard 5 from 2015 to 2016. Results show high short term (100-1000 nmol L ${ }^{-1}$ within hours) and seasonal variation, as well as higher (2-7 times) methane concentrations compared to previous measurements. Rapid variability is explained by uneven distribution of seepage and changing ocean current directions. No overt influence of tidal hydrostatic pressure or water temperature variations on methane concentration was observed, but an observed negative correlation with temperature at the 246 site fits with hypothesized seasonal blocking of lateral methane pathways in the sediments. Negative correlation between bottom water methane concentration/variability and wind forcing, concomitant with signs of weaker water column stratification indicates increased potential for methane release to the atmosphere in fall/winter. We highlight uncertainties in methane inventory estimates based on discrete water sampling and present new information about short- and long-term methane variability which can help constrain future estimates of seabed methane seepage.
\end{abstract}

\section{Introduction}

Unexplained changes in atmospheric methane $\left(\mathrm{CH}_{4}\right)$ mole fraction motivates research in understanding and quantifying nonanthropogenic sources (Saunois et al., 2020). The atmospheric forcing of $\mathrm{CH}_{4}$ is particularly sensitive to changes in emission rates due to a high warming potential and short lifetime. Improved knowledge about atmospheric $\mathrm{CH}_{4}$ fluxes is therefore crucial to constrain future climate projections (Pachauri and Meyer, 2014; Myhre et al., 2016b). These properties of atmospheric $\mathrm{CH}_{4}$ also makes reduced anthropogenic $\mathrm{CH}_{4}$ emissions a potential solution for rapid climate change mitigation (Saunois et al., 2016). A global global effort to cut greenhouse gas emissions through international agreements is, however, dependant on precise estimates of sources and sinks to verify contributions from different nations. 
https://doi.org/10.5194/os-2021-85

Preprint. Discussion started: 13 September 2021

(c) Author(s) 2021. CC BY 4.0 License.

Seabed seepages is considered a minor source of atmospheric $\mathrm{CH}_{4}$, but with high uncertainty in current and predicted emission estimates (Saunois et al., 2016). Current estimates suggest a total contribution of 7 (5-10) $\mathrm{Tg} \mathrm{y}^{-1}$ (Etiope et al., 2019; Saunois et al., 2020), which is $\sim 1 \%$ of the total $\mathrm{CH}_{4}$ emissions to the atmosphere. Methane is released from the seabed as free gas (bubbles) and dissolved gas in sediment pore water. Bubbles rise quickly towards the sea surface, but most $\mathrm{CH}_{4}$ dissolves near the seafloor because of gas exchange across the bubble rims and bubble dissolution (McGinnis et al., 2006; Jansson et al., 2019a). Dissolved $\mathrm{CH}_{4}$ is dispersed and advected by ocean currents (Silyakova et al., 2020) and is continuously transformed to carbon dioxide $\left(\mathrm{CO}_{2}\right)$ by bacterial aerobic oxidation (Hanson and Hanson, 1996; Reeburgh, 2007). These processes significantly limit the lifetime of $\mathrm{CH}_{4}$ in the water column and the amount of $\mathrm{CH}_{4}$ that can reach the atmosphere is highly dependent on the depth where the seepage occurs (McGinnis et al., 2006; Graves et al., 2015). Intense $\mathrm{CH}_{4}$ seepage at shallow depths in coastal areas and on continental shelves is therefore the main potential source of seabed $\mathrm{CH}_{4}$ to the atmosphere.

The shallow continental margins of the Arctic Ocean store large amounts of $\mathrm{CH}_{4}$ as free gas, gas dissolved in pore water fluid, and gas hydrates (Ruppel and Kessler, 2017), i.e. clathrate structures composed of water trapped by hydrocarbon molecules formed and kept stable at low temperature and high pressure (Sloan, 1998). Methane trapped in hydrates or in subsea permafrost, as well as hydrate sealed free gas reservoirs can be destabilized by increasing bottom water temperature, resulting in a potential positive climate feedback loop (Westbrook et al., 2009; Shakhova et al., 2010; Ruppel and Kessler, 2017).

Studies on $\mathrm{CH}_{4}$ inventory, distribution and release in the Arctic Ocean are mainly based on research cruise data from late spring to early fall, when ice and weather conditions allow field work in the region (Gentz et al., 2014; Sahling et al., 2014; Mau et al., 2017), whereas winter data is sparse. Bottom water temperature (Westbrook et al., 2009; Reagan et al., 2011; Ferré et al., 2012; Braga et al., 2020), water mass origins (Steinle et al., 2015), micro-seismicity (Franek et al., 2017), and hydrostatic pressure (Linke et al., 2009; Römer et al., 2016) have all been proposed to be linked with sources and sinks of $\mathrm{CH}_{4}$ in the water column. These processes act on a wide range of time-scales, from hours (e.g. hydrostatic pressure) to decades (bottom water temperature). Without a better understanding of the spatial and temporal variability of $\mathrm{CH}_{4}$ in Arctic Seep sites, it is challenging to untangle these processes. Unconstrained local variability in $\mathrm{CH}_{4}$ seepage and concentration also imposes a high degree of uncertainty on $\mathrm{CH}_{4}$ inventory estimates (Saunois et al., 2020). The combination of climate sensitive $\mathrm{CH}_{4}$ storages, vast shallow ocean regions and limited data availability highlight the need for more understanding of seabed $\mathrm{CH}_{4}$ seepage on Arctic shelves.

To assess the aforementioned challenges, we have obtained, analyzed and compared unique year-round underwater multiparameter time series from two seafloor observatories deployed at two intense $\mathrm{CH}_{4}$ seep sites on the western Svalbard continental shelf (Figure 1) where no $\mathrm{CH}_{4}$ measurements have previously been done in winter season. We combine high frequency physical (ocean currents, temperature, salinity, pressure) and chemical $\left(\mathrm{O}_{2}, \mathrm{CO}_{2}, \mathrm{CH}_{4}\right)$ data to perform hypothesis testing and provide new insights on $\mathrm{CH}_{4}$ distribution, content, as well as variability on short (minutes) and long (seasonal) timescales. 
https://doi.org/10.5194/os-2021-85

Preprint. Discussion started: 13 September 2021

\subsection{Regional Settings}

Two observatories $\left(\mathrm{O}_{91}\right.$ and $\left.\mathrm{O}_{246}\right)$ were deployed from June 2015 (CAGE 15-3 cruise) to May 2016 (CAGE 16-4 cruise) from R/V Helmer Hanssen at the inter-trough shelf region between Isfjorden and Kongsfjorden, west of Prins Karls Forland (PKF). The $\mathrm{O}_{91}$ observatory was deployed at $91 \mathrm{~m}$ water depth on the continental shelf $\left(78.561^{\circ} \mathrm{N}, 10.142^{\circ} \mathrm{E}\right)$ and the $\mathrm{O}_{246}$ observatory was deployed at $246 \mathrm{~m}$ water depth further offshore close to the shelf break $\left(78.655^{\circ} \mathrm{N}, 9.433^{\circ} \mathrm{E}\right.$, Figure 1$)$.

Both sites were located in areas with thousands of previously mapped $\mathrm{CH}_{4}$ gas seeps (e.g. (Sahling et al., 2014; VelosoAlarcón et al., 2019; Silyakova et al., 2020), this work, see Figure 1), often referred as "flares" due to the appearance of bubble streams in echo-sounder data. Nonetheless, atmospheric sampling in this region suggests that any emissions to the atmosphere are small (Platt et al., 2018). Gas accumulation at the $\mathrm{O}_{246}$ seep site has been suggested to be a result of gas migration in permeable layers within the seabed from deeper free gas or hydrate reservoirs (Rajan et al., 2012; Sarkar et al., 2012; VelosoAlarcón et al., 2019), while seepage at site $\mathrm{O}_{91}$ has been attributed to thawing sub-sea permafrost due to ice sheet retreat at the end of the last glaciation (Sahling et al., 2014; Portnov et al., 2016). Water sampling have indicated high temporal variability with bottom water concentrations (average) changing from $200 \mathrm{nmol} \mathrm{L}^{-1}$ within 1 week in July 2014 at $\mathrm{O}_{91}$ (Myhre et al., 2016a) and $\sim 80 \mathrm{nmol} \mathrm{L}^{-1}$ within 20 hours (two single point measurements) at $\mathrm{O}_{246}$ in August 2010 (Gentz et al., 2014). A consistent pattern of decreasing concentrations from the sea floor to the sea surface at both sites (400 to $<8 \mathrm{nmol} \mathrm{L}^{-1}$ at $\mathrm{O}_{91}$ (Myhre et al., 2016a)) and from to $>500$ to $<20 \mathrm{nmol} \mathrm{L}^{-1}$ at $\mathrm{O}_{246}$ (Gentz et al., 2014)) has also been observed. Further offshore, continuous measurements from a towed fast response underwater laser spectrometer also revealed very high spatial $\mathrm{CH}_{4}$ variability (Jansson et al., 2019b).

The local water masses are characterized by exchange and convergence of the warm, saline Atlantic Water (AW, Temperature $\mathrm{T}>3^{\circ} \mathrm{C}$ and absolute salinity $\mathrm{S}_{A}>34.65$ ) in the West Spitsbergen Current (WSC) (Beszczynska-Möller et al., 2012) and the colder, fresher Arctic Water (ArW, $-1.5<\mathrm{T}<1^{\circ} \mathrm{C}, 34.3<\mathrm{S}_{A}<34.8$ ) in the Coastal Current (CC) (Hopkins, 1991) combined with seasonal cooling, ice formation, and freshwater input from land (Nilsen et al., 2016) (Figure 1). Local mixing rates can be strongly affected by synoptic scale weather systems, causing upwelling and disruption of the front between the two ocean currents (Saloranta and Svendsen, 2001; Cottier et al., 2007). Freshwater input in summer stratifies the water column, while cooling, storm activity and sea ice formation can facilitate vertical mixing in winter (Saloranta and Svendsen, 2001; Nilsen et al., 2016).

\section{Methods}

The "K-Lander" ocean observatories were designed to monitor $\mathrm{CH}_{4}$ release and associated physical and chemical parameters in challenging environments (see Appendix A). A launcher equipped with camera and telemetry allowed for safe deployment at a site selected by visual control. Observatory $\mathrm{O}_{91}$ recorded data from 2 July 2015 to 6 May 2016, while $\mathrm{O}_{246}$ recorded data from 1 July until 3 October 2015, when data recording ceased due to an electrical malfunction.

Both observatories were equipped with an Acoustic Doppler Current Profiler (ADCP), a CTD with oxygen optode, and Contros HydroC $\mathrm{CO}_{2}$ and $\mathrm{CH}_{4}$ sensors (see Figure A1 and Table B1). We calculated correlation coefficient (R) matrices to 


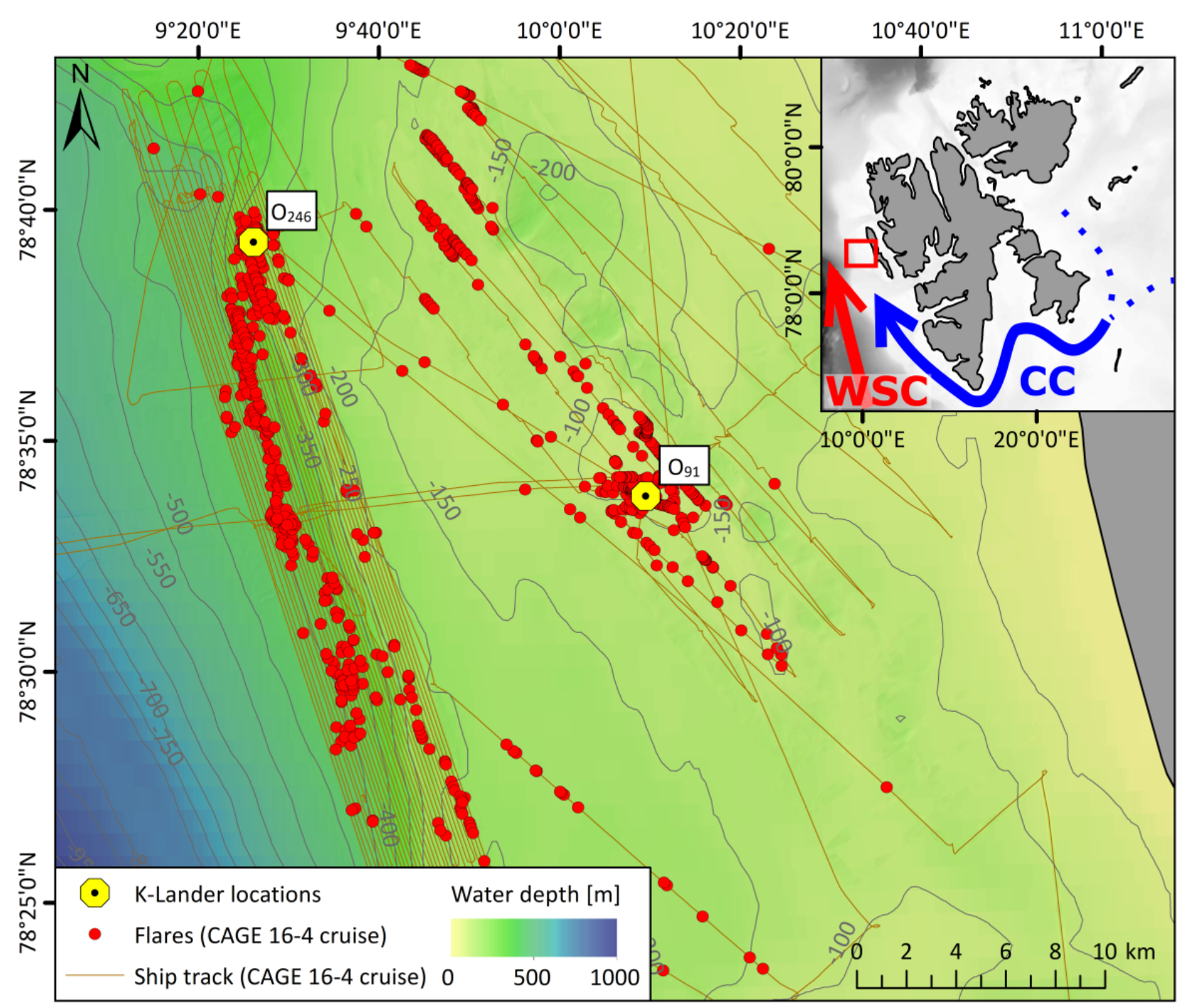

Figure 1. Bathymetry of the study area with location of the observatories $\mathrm{O}_{91}$ and $\mathrm{O}_{246}$ offshore western Svalbard. Flares detected by singlebeam echo sounder survey prior to recovering the observatories (May 2016, cruise CAGE 16-4) are indicated with red dots and ship tracks as brown lines. The inset map shows the working area (red square) offshore Svalbard. WSC and CC refer to the warm West Spitsbergen Current and cold Coastal Current, respectively. 
give an overview of linear relationships between the measured parameters. We mapped the flares in the area using single-beam echo-sounder data collected during the observatory recovery cruise in 2016 (CAGE 16-4, Figure 1) and estimated gas flow rates using the FlareHunter software (Veloso et al., 2015). Additionally, we obtained $10 \mathrm{~m}$ wind reanalysis data from the ERAInterim database. Further description of general post-processing, technical features of the data and measurement accuracies are outlined in Appendix B and Table B1.

We calculated seawater density (McDougall and Barker, 2011) and $\mathrm{CH}_{4}$ solubility (Kossel et al., 2013) using the CTD data. A CTD cast (SBE plus $24 \mathrm{~Hz}$ ) prior to the $\mathrm{O}_{91}$ recovery (6 May, 2016) showed a salinity drift in the conductivity sensor of around -0.4 . Post-calibration, inspection of the conductivity signal and potential water mass mixing end-members indicates that this might have been caused by mud pollution occurring in late 2015 or early 2016.

High power consumption of the Contros HydroC $\mathrm{CH}_{4}$ and $\mathrm{CO}_{2}$ sensors required a power cycling mode to allow for longterm monitoring while simultaneously capturing rapid short-term variability. Partial pressure of $\mathrm{CH}_{4}$ and $\mathrm{CO}_{2}$ was therefore measured continuously for 24 hours every 21 days, and for one hour every day (see Table B1). $\mathrm{CH}_{4}$ concentration data were corrected for slow response time following Dølven et al., (In prep.) onto a 3 minute interval grid and converted to absolute concentration (see Appendix C), which is the default " $\mathrm{CH}_{4}$ concentration" discussed and described in this text. Faulty pumps in the $\mathrm{CO}_{2}$ sensors ambiguously increased the response time, preventing us from performing response time correction and making $\mathrm{CO}_{2}$ data suitable only for long-term qualitative analysis.

\section{Results}

\subsection{Time series at site $\mathbf{O}_{91}$}

Dissolved $\mathrm{CH}_{4}$ concentration at site $\mathrm{O}_{91}$ ranged from $5 \mathrm{nmol} \mathrm{L}{ }^{-1}$ (6 December in 2015) to $1348 \mathrm{nmol} \mathrm{L}^{-1}$ (20 August in 2015) (Figure 2a) following a log-normal distribution, with a mean and median of 227 and 165 nmol $\mathrm{L}^{-1}$, respectively. Large variations ( $>100$ up to almost $1000 \mathrm{nmol} \mathrm{L}{ }^{-1}$ ) in $\mathrm{CH}_{4}$ concentration occurred on short time-scales $(<1$ hour) throughout the measurement period (see Figure 2a, d, and all 24-hour periods in Appendix D) with an average range for all the 24-hour periods of $840 \mathrm{nmol} \mathrm{L}{ }^{-1}$ and median rate of change (ROC) of $3.2 \mathrm{nmol} \mathrm{L}-1 \mathrm{~min}^{-1}$. We also observe a long-term trend of

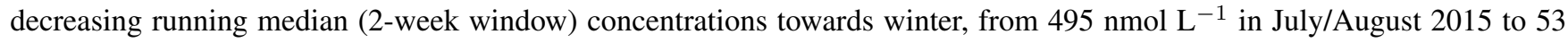
nmol L ${ }^{-1}$ in January 2016 (Figure 2). There was a relatively weak, but significant negative correlation between the wind speed and $\mathrm{CH}_{4}$ concentration $\left(\mathrm{R}_{R T C}=-0.33\right)$, but otherwise weak to non-existent linear relationships between $\mathrm{CH}_{4}$ concentration and the measured ocean parameters (Table 1).

$\mathrm{CO}_{2}$ averaged $403 \mu \mathrm{atm}$ with a decrease from mid-November 2015 ( 400 $\mu$ atm) until 6 May ( 391 $\mu$ atm) in 2016 (Figure 2a). $\mathrm{CO}_{2}$ dropped to $\sim 305 \mu$ atm on 24 August, concurrent with a rapid decrease in salinity (-0.5), increase in temperature and oxygen, and high $\mathrm{CH}_{4}$ concentration. The oxygen increase rules out methanogenesis. Instead, there might be at least two explanations for this reduction of $\mathrm{CO}_{2}$ and enrichment of $\mathrm{CH}_{4}$ : i) water column mixing brings oxygen-rich, warm and fresh surface water to deeper depth, and with it $\mathrm{CO}_{2}$ depleted water or ii) methane enrichment by zooplankton following the summer bloom. 
https://doi.org/10.5194/os-2021-85

Preprint. Discussion started: 13 September 2021

(c) Author(s) 2021. CC BY 4.0 License.

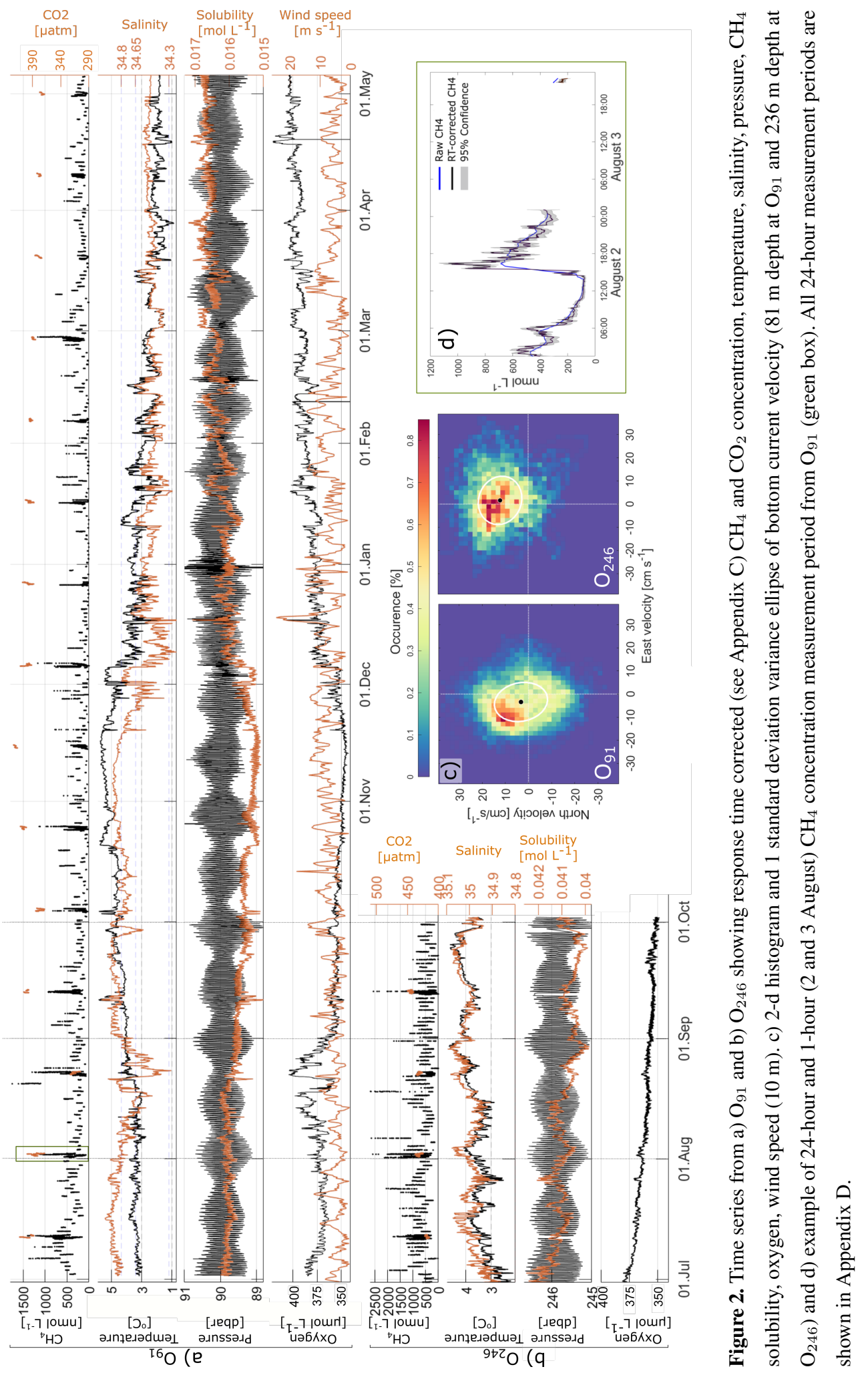


Table 1. Correlation coefficients between variables at $\mathrm{O}_{91}$. "RTC $\mathrm{CH}_{4}$ " and "Raw $\mathrm{CH}_{4}$ " refers to response time corrected and untreated $\mathrm{CH}_{4}$ (see Appendix C). Units used are mol L ${ }^{-1},{ }^{o} \mathrm{C}$, salinity, mol L ${ }^{-1}$, dbar, $\mathrm{mol} \mathrm{L}^{-1}, \mathrm{~m} \mathrm{~s}^{-1}$, and $\mu$ atm for dissolved $\mathrm{CH}_{4}$, temperature, $\mathrm{PSU}_{\text {, }}$ dissolved oxygen, pressure, $\mathrm{CH}_{4}$ solubility, wind speed, and partial pressure of $\mathrm{CO}_{2}$, respectively.

\begin{tabular}{l|ccccccccc}
\hline & $\mathrm{RTC} \mathrm{CH}_{4}$ & $\mathrm{Raw} \mathrm{CH}_{4}$ & Temperature & Salinity & Oxygen & Pressure & Solubility & Wind speed & $\mathrm{CO}_{2}$ \\
\hline $\mathrm{RTC} \mathrm{CH}_{4}$ & 1 & 0.91 & -0.06 & 0.23 & 0.03 & 0.08 & 0.06 & -0.33 & -0.25 \\
Raw $\mathrm{CH}_{4}$ & 0.91 & 1 & -0.07 & 0.27 & 0.03 & 0.10 & 0.06 & -0.37 & -0.31 \\
Temperature & -0.06 & -0.07 & 1 & 0.69 & -0.94 & -0.01 & -0.99 & 0.37 & 0.29 \\
Salinity & 0.23 & 0.27 & 0.69 & 1 & -0.78 & -0.06 & -0.58 & 0.06 & 0.46 \\
Oxygen & 0.03 & 0.03 & -0.94 & -0.78 & 1 & 0.02 & 0.85 & -0.33 & -0.67 \\
Pressure & 0.08 & 0.10 & -0.01 & -0.06 & 0.02 & 1 & 0.16 & 0.00 & -0.10 \\
Solubility $\left(\mathrm{CH}_{4}\right)$ & 0.06 & 0.06 & -0.99 & -0.58 & 0.85 & 0.16 & 1 & -0.35 & -0.30 \\
Wind speed & -0.33 & -0.37 & 0.37 & 0.06 & -0.33 & 0.00 & -0.35 & 1 \\
$\mathrm{CO}_{2}$ & -0.25 & -0.31 & 0.29 & 0.46 & -0.67 & -0.10 & -0.30 & 0.52 \\
\hline
\end{tabular}

Bottom water temperature increased steadily from $\sim 3$ in July to $\sim 5.5^{\circ} \mathrm{C}$ in October/November 2015 , with occasional sharp shifts $\left(\mathrm{T} \pm 1^{\circ} \mathrm{C}\right.$ ) occurring within hours to days (Figure $2 \mathrm{~b}$ ). Temperature then decreased from the beginning of December to $\sim 1.8^{\circ} \mathrm{C}$ at the end of the deployment in May 2016, showing more frequent and stronger episodes of rapid temperature shifts ( $\mathrm{T} \pm 2^{\circ} \mathrm{C}$ also occurring on hours-days). Despite uncertainty in salinity data, it is worth noting that these rapid shifts in temperature and salinity was reproduced by the Svalbard 800 model in the same area (Silyakova et al., 2020) by eddy activity.

Hydrostatic pressure was mostly governed by tides (94.5\% of variance) with dominant semi-diurnal M2 tide (M2 refers to a tidal constituent with period 12.42 hours, see e.g. Gerkema (2019)). Amplitudes varied from $\sim 1.2$ to 1.5 meter during neap and spring cycles (Figure 2c).

The calculated $\mathrm{CH}_{4}$ solubility decreased from $0.016 \mathrm{~mol} \mathrm{~L}-1$ in July to $0.015 \mathrm{~mol} \mathrm{~L}^{-1}$ in the end of November 2015 , and increased to almost $0.017 \mathrm{~mol} \mathrm{~L}^{-1}$ in May 2016 (Figure 2c). This long-term trend was mainly caused by temperature variability $(\mathrm{R}=-0.99)$, while tidal pressure changes caused a semi-diurnal variation of $\pm \sim 0.005 \mathrm{~mol} \mathrm{~kg}^{-1}$.

Dissolved $\mathrm{O}_{2}$ decreased from $\sim 385 \mu \mathrm{mol} \mathrm{L}^{-1}$ in July 2015 to $\sim 350 \mu \mathrm{mol} \mathrm{L}^{-1}$ at the beginning of December, and increased to $\sim 400 \mu \mathrm{mol} \mathrm{L}{ }^{-1}$ towards 6 May, 2016 (Figure $2 \mathrm{~d}$ ) and followed temperature inversely (R=-0.94), with similar long and short-term variability.

The averaged bottom water current ( $81 \mathrm{~m}$ above the seafloor) was $4 \mathrm{~cm} \mathrm{~s}^{-1}$ in a northwestward direction (321 $\left.{ }^{\circ} \mathrm{N}\right)($ Figure $2 \mathrm{c})$. The current usually had one anti-clockwise rotation every 23.93 hour period, corresponding to the diurnal K1 tidal constituent (tide with period 23.93 hours, see Gerkema (2019)) with a secondary semi-diurnal (M2) modulation. 


\subsection{Time series at site $\mathbf{O}_{246}$}

$\mathrm{CH}_{4}$ concentration at site $\mathrm{O}_{246}$ ranged from $10 \mathrm{nmol} \mathrm{L}^{-1}$ on 21 September, 2015 to $2727 \mathrm{nmol} \mathrm{L}^{-1}$ on 18 August 2015, following a log-normal distribution with an average and median of 577 and $600 \mathrm{nmol} \mathrm{L}^{-1}$. The median $\mathrm{RoC}$ of $\mathrm{CH}_{4}$ was almost 20 times higher compared to site $\mathrm{O}_{91}$ with $31 \mathrm{nmol} \mathrm{L}^{-1} \min ^{-1}$ (Figure $2 \mathrm{~b}$ and Appendix D). There was also clear diurnal periodicity in $\mathrm{CH}_{4}$ concentration at $\mathrm{O}_{246}$. The long-term trend (2-week running mean) shows decreasing concentrations until 3 October 2015 (end of the measuring period, Figure 2b). Dissolved $\mathrm{O}_{2}$ decreased from $\sim 380 \mu \mathrm{mol} \mathrm{L}^{-1}$ to $\sim 300 \mu \mathrm{mol}$ $\mathrm{L}^{-1}$ and was negatively correlated with water temperature ( $\mathrm{R}=-0.61$, see Table 2 for complete correlation matrix).

Table 2. Correlation coefficients between variables at $\mathrm{O}_{91}$. "RTC $\mathrm{CH}_{4}$ " and "Raw $\mathrm{CH}_{4}$ " refers to response time corrected and untreated $\mathrm{CH}_{4}$ (see Appendix C). Units used are $\mathrm{mol} \mathrm{L}{ }^{-1},{ }^{o} \mathrm{C}$, salinity, $\mathrm{mol} \mathrm{L}{ }^{-1}$, dbar, mol L ${ }^{-1}, \mathrm{~m} \mathrm{~s}^{-1}$, and $\mu$ atm for dissolved $\mathrm{CH}_{4}$, temperature, PSU, dissolved oxygen, pressure, $\mathrm{CH}_{4}$ solubility, wind speed, and partial pressure of $\mathrm{CO}_{2}$, respectively.

\begin{tabular}{|c|c|c|c|c|c|c|c|c|c|}
\hline & $\mathrm{RTC} \mathrm{CH}_{4}$ & Raw $\mathrm{CH}_{4}$ & Temperature & Salinity & Oxygen & Pressure & Solubility & Wind speed & $\mathrm{CO}_{2}$ \\
\hline $\mathrm{RTC} \mathrm{CH}_{4}$ & 1 & 0.78 & -0.31 & -0.24 & 0.30 & 0.15 & 0.33 & -0.29 & -0.13 \\
\hline Raw $\mathrm{CH}_{4}$ & 0.78 & 1 & -0.45 & 0.26 & 0.48 & 0.10 & 0.45 & -0.44 & -0.09 \\
\hline Temperature & -0.31 & -0.45 & 1 & 0.87 & -0.61 & -0.02 & -0.99 & 0.38 & 0.22 \\
\hline Salinity & -0.24 & -0.26 & 0.87 & 1 & -0.22 & -0.03 & -0.87 & 0.07 & 0.13 \\
\hline Oxygen & 0.30 & 0.48 & -0.61 & -0.22 & 1 & 0.06 & 0.59 & -0.65 & -0.41 \\
\hline Pressure & 0.15 & 0.01 & -0.02 & -0.03 & 0.06 & 1 & 0.16 & -0.05 & 0.14 \\
\hline Solu $\left(\mathrm{CH}_{4}\right)$ & 0.33 & 0.45 & -0.99 & -0.87 & 0.59 & 0.16 & 1 & 0.38 & -0.20 \\
\hline Wind speed & -0.29 & -0.44 & 0.38 & 0.07 & -0.65 & -0.05 & 0.38 & 1 & 0.18 \\
\hline $\mathrm{CO}_{2}$ & -0.13 & -0.09 & 0.22 & 0.13 & -0.41 & 0.14 & -0.20 & 0.41 & 1 \\
\hline
\end{tabular}
until October 2015 (Figure 2b), with AW dominance throughout the measuring period. Rapid shifts of around $\pm 1{ }^{\circ} \mathrm{C}$ and 0.05 salinity occurred occasionally over a period of hours to days.

Variance in hydrostatic pressure was mainly explained by the tides (95.2\%) which was mainly governed by the semi-diurnal M2 tide, with weaker diurnal and fortnightly modulation (Figure $2 \mathrm{~b}$ ). Changes in pressure varied from $\sim 1.2$ to $\sim 1.5 \mathrm{~m}$ during periods of neap and spring tide.

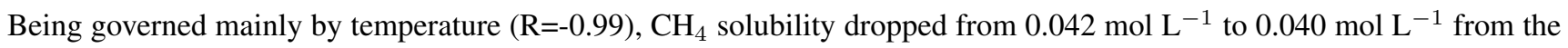
deployment in July until October 2015, with a semi-diurnal variation of $\sim 0.005$ mol $\mathrm{L}^{-1}$ due to tidal changes in hydrostatic pressure.

The averaged current was $\sim 10 \mathrm{~cm} \mathrm{~s}^{-1}$ northward $\left(7^{\circ} \mathrm{N}\right)$ (Figure $\left.2 \mathrm{c}\right)$. Variability in the along-slope current (direction $\left.-10^{\circ} \mathrm{N}\right)$ was strongly related to the semi-diurnal M2 tidal component, while the cross-slope currents were governed by the diurnal K1 frequency. The bottom water current rotated counter-clockwise with a period of 23.93 hours (K1 tidal constituent), with semi-diurnal modulation in the along-slope component. Dissolved $\mathrm{CH}_{4}$ concentration was weakly anti-correlated with wind 
https://doi.org/10.5194/os-2021-85

Preprint. Discussion started: 13 September 2021

(c) Author(s) 2021. CC BY 4.0 License.

speed $(\mathrm{R}=-0.29)$, temperature $(\mathrm{R}=-0.31)$, salinity $(\mathrm{R}=-0.24)$, and positively correlated with $\mathrm{CH}_{4}$ solubility $(\mathrm{R}=0.33)$ and oxygen $(\mathrm{R}=0.3)$.

\section{Discussion}

\section{1 $\mathrm{CH}_{4}$ variability}

Combining mapped flares and flow rates from the recovery cruise (May 2016) with bottom water current velocity (9 meters above the seafloor) reveals that $\mathrm{CH}_{4}$ concentration was strongly affected by whether water was advected from areas where we mapped strong or weak seepage in May 2016 (Figure 3). Strong seeps (flow rate $>200 \mathrm{~mL}^{-1} \mathrm{~min}^{-1}$ ) were mainly located between $\sim 30$ and $80 \mathrm{~m}$ to the north/northeast of site $\mathrm{O}_{91}$ and only weak and more distant seepage was observed south-west of the observatory (Figure 3a). Consequently, averaged $\mathrm{CH}_{4}$ concentration from water coming from north-east was $\sim 440 \mathrm{nmol}$ $\mathrm{L}^{-1}$, while water from south-west averaged $\sim 100 \mathrm{nmol} \mathrm{L}{ }^{-1}$. Similarly, a strong $\mathrm{CH}_{4}$ seep (flow rate $\sim 1200 \mathrm{~mL} \mathrm{~min}^{-1}$ ) was mapped $\sim 40 \mathrm{~m}$ north of site $\mathrm{O}_{246}$, making water advected from this direction highly elevated in $\mathrm{CH}_{4}$ with an average of $\sim 1400$ $\mathrm{nmol} \mathrm{L}{ }^{-1}$ compared to the overall average of $577 \mathrm{nmol} \mathrm{L}^{-1}$ (Figure 3b). The rapid changes in dissolved $\mathrm{CH}_{4}$ can to a high degree be explained by this relationship, due to the high variability in ocean current velocity. That this relationship holds for most of the measuring period also shows that seepage and seep configuration did not change significantly from July 2015 to May 2016 (no winter season seep hibernation as observed in Ferré et al. (2020)) and that dissolved $\mathrm{CH}_{4}$ was efficiently dispersed in high concentrations in the whole seepage area.

Furthermore, daily $\mathrm{CH}_{4}$ concentrations at site $\mathrm{O}_{91}$ were higher on average than the 24-hour measurements (313 vs. 200 nmolL ${ }^{-1}$ ). This can explained by the comparable measurement periodicity (24 hours) and tidal periodicity (23.93 hours) in the ocean currents, resulting in predominantly eastward advection during daily measurements, thus systematically transferring more water from a weak seepage area (Figure 3). We did not observe this effect at site $\mathrm{O}_{246}$, most likely due to less tidal variance in the current direction (Figure 2b). Nonetheless, this systematic tide induced bias on the daily measurements at site $\mathrm{O}_{91}$ highlights the importance of taking the oceanographic conditions into account to avoid misinterpretation of variability.

Since currents are mostly northward and seepage are mostly located to the north of both observatories, averaged $\mathrm{CH}_{4}$ concentrations are also most likely lower than the average over the immediate surrounding area (Figure 3). Despite this, the observatory data show higher average $\mathrm{CH}_{4}$ concentrations than previously reported. In the area surrounding site $\mathrm{O}_{91}$, Silyakova et al., (2020) reported average concentration of 92, 70, and $61 \mathrm{nmol} \mathrm{L}^{-1}$ in June 2014, July 2015, and May 2016, respectively, based on discrete water sampling. Averaged $\mathrm{CH}_{4}$ concentrations measured at site $\mathrm{O}_{91}$ in July 2015 and May 2016 were 566 and $110 \mathrm{nmol} \mathrm{L}^{-1}$ respectively, i.e. around eight and two times higher than values reported by Silyakova et al., (2020). The maximum $\mathrm{CH}_{4}$ concentration at $\mathrm{O}_{91}$ of $1789 \mathrm{nmol} \mathrm{L}^{-1}$ on 20 August 2015 also significantly exceeds the previously maximum recorded concentration in the area of $480 \mathrm{nmol} \mathrm{L}^{-1}$ (July 2014, Silyakova et al., 2020).

At site $\mathrm{O}_{246}$ the August 2016 average $\left(564 \mathrm{nmol} \mathrm{L}^{-1}\right.$ ) was eight times higher than what Gentz et al., (2014) found in August $2010\left(70 \mathrm{nmol} \mathrm{L}^{-1}\right)$, using an altimeter-controlled CTD towed at 2 meter above the seafloor. Maximum concentration 
https://doi.org/10.5194/os-2021-85

Preprint. Discussion started: 13 September 2021

Ocean Science

(c) Author(s) 2021. CC BY 4.0 License.

Discussions

(c) (i)
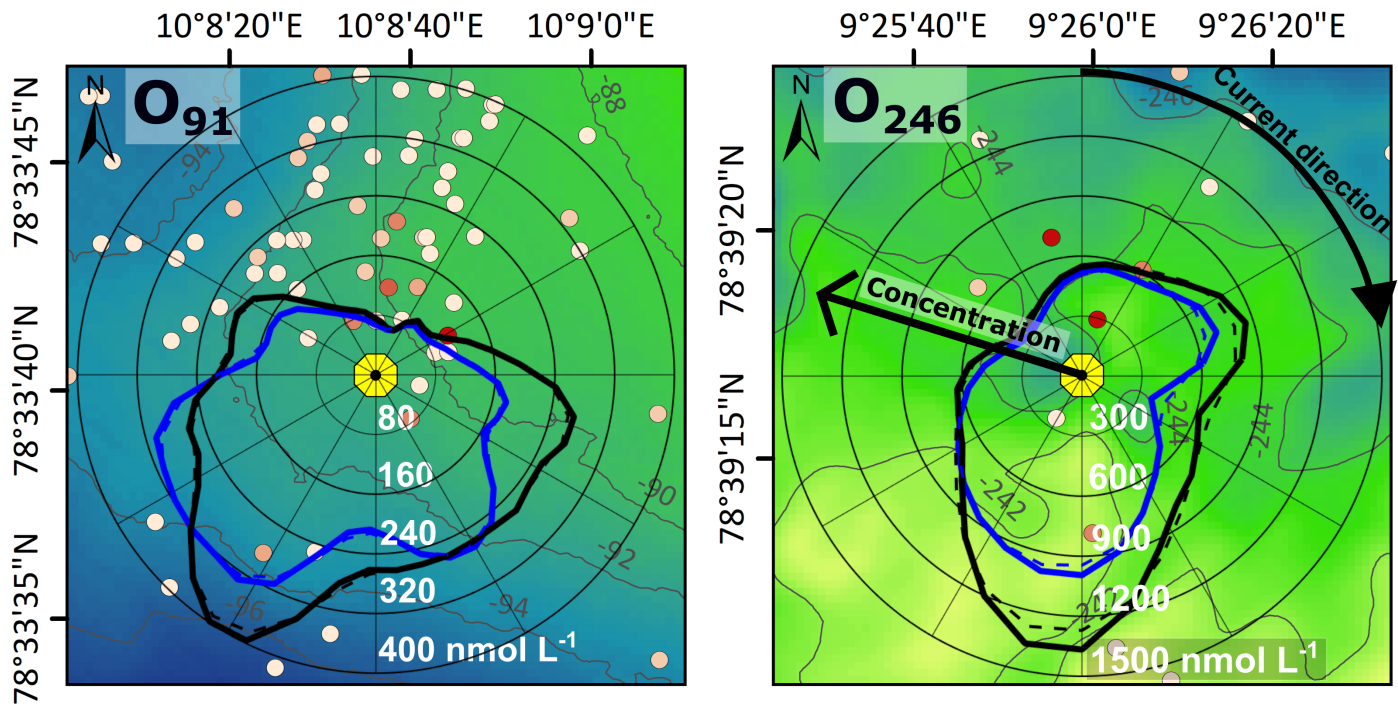

$0 \quad 50100150 \mathrm{~m}$

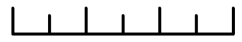

- Raw $\mathrm{CH}_{4}$ data

- $\mathrm{RTC} \mathrm{CH}_{4}$ data

Flow rate $[\mathrm{ml} / \mathrm{min}]$

- > 500

- $400-500$

- $300-400$

- $200-300$

- $100-200$

- $50-100$

$<50$

Figure 3. $\mathrm{O}_{91}$ (left) and $\mathrm{O}_{246}$ (right) location (yellow dot) as well as flow rates from flares mapped in its vicinity during CAGE 16-4 (colorscale). Background color (grene-blue) illustrate seafloor bathymetry. Compass diagram show the relationship between ocean current direction (angle) and $\mathrm{CH}_{4}$ concentration (distance from center, black is response time corrected (RTC) data and raw data is in blue).

in August 2016 also significantly exceeded previous observations, with $2661 \mathrm{nmol} \mathrm{L}^{-1}$ compared to $524 \mathrm{nmol} \mathrm{L}^{-1}$ measured by Gentz et al., (2014).

These differences could be a result of temporal, local or regional differences in $\mathrm{CH}_{4}$ concentration. However, strong vertical gradients in dissolved $\mathrm{CH}_{4}$ are well documented at both seep sites (Gentz et al., 2014), and our sensors measured closer to the seafloor (1.2 m above seafloor), compared to Gentz et al., (2014) (2 m above seafloor) and Silyakova et al., (2020) (5 to 15 $\mathrm{m}$ above seafloor). Additionally, the observatories were deployed close to seeps using a launcher as opposed to "blind" water sampling from ship-born rosette. Methane was also measured in situ, thereby avoiding potential $\mathrm{CH}_{4}$ outgassing after retrieval of water samples (Schlüter et al., 1998).

We documented high local variability, steep concentration gradients, strong connection to highly variable ocean currents and higher $\mathrm{CH}_{4}$ concentrations than previously reported in the same areas. Dissolved $\mathrm{CH}_{4}$ within shallow seep sites where the gas can bypass the oceanic sinks often present heterogeneous distribution and rapid temporal variability (Myhre et al., 2016a; Mau et al., 2017; Veloso-Alarcón et al., 2019). Our results show that the variability in space and time at our two seep sites are higher and faster than previously reported, at least in bottom water ( $<2 \mathrm{~m}$ above the seafloor). This underlines an important caveat when using snap-shot surveys and interpolation/extrapolation techniques to estimate $\mathrm{CH}_{4}$ inventories and fluxes. As shown herein, $\mathrm{CH}_{4}$ concentration at our locations can change by up to 2 orders of magnitude within hours (Figure 2d), while ship-based "snapshot" surveys often take place over several days. Using ship based discrete water sampling and interpolation/extrapolation techniques which assumes an even/linear distribution when the distribution of $\mathrm{CH}_{4}$ is in fact patchy, may well explain discrepancies between top-down and bottom-up approaches to estimate $\mathrm{CH}_{4}$ inventories in, and 
https://doi.org/10.5194/os-2021-85

Preprint. Discussion started: 13 September 2021

fluxes from the ocean (e.g. discrepancies between Shakhova et al., (2010) and Berchet et al., (2016)). It is also important to acknowledge that ocean currents are often periodic and to a certain degree systematic in their behavior, implying potential systematic measurement errors.

Our findings highlight the advantage of towed or autonomous instrumentation capable of providing continuous $\mathrm{CH}_{4}$ data giving a considerably better coverage and representation of the $\mathrm{CH}_{4}$ distribution in a much shorter time frame (e.g. Sommer et al., (2015) and Canning et al., (2021)). They also stress the importance of having a systematic grid when collecting water samples for inventory estimates in intense seep areas, thereby allowing the law of large numbers to apply. Assuming a lognormal distribution, which better reflects the uneven spread of $\mathrm{CH}_{4}$, when applying interpolation/extrapolation techniques could further limit estimation errors. It also shows the importance of getting a good overview of the ocean currents and location of $\mathrm{CH}_{4}$ seeps to mitigate uncertainties in sparsely sampled areas to avoid potential systematic errors.

\subsection{Hydrostatic pressure}

Tidal changes in hydrostatic pressure can trigger $\mathrm{CH}_{4}$ release by build-up of $\mathrm{CH}_{4}$ in sediment pore-water at rising tide and subsequent release when pore pressure decreases at falling tide as observed at the Hikurangi Margin (Linke et al., 2009) and Clayoquot slope (Römer et al., 2016). Our study sites differs from these sites in depth (they are $>600 \mathrm{~m}$ ) and in tidal amplitude (4 $\mathrm{m}$ at Calyoquot slope compared to 1.5 at PKF). Linke et al., (2010) and Römer et al., (2016) also observed bubbles hydroacoustically, while we measure dissolved $\mathrm{CH}_{4}$ which is strongly affected by the (also tidally dependent) current direction (Figure 3).

To constrain this effect on $\mathrm{CH}_{4}$ concentration, we separated the data into overlapping portions depending on the current direction ( $12^{\circ}$ and $30^{\circ}$ for $\mathrm{O}_{91}$ and $\mathrm{O}_{246}$, respectively) and calculated standard scores of $\mathrm{CH}_{4}$ concentration for each portion which are less dependent on current direction. We used larger current direction intervals for $\mathrm{O}_{246}$ due to the shorter data set. We then binned all the $\mathrm{z}$-scored $\mathrm{CH}_{4}$ data according to when the data were collected in relation to the M2 governed tidal cycle peak using overlapping 30 minute bins (the M2 tide explains $79.2 \%$ and $80.3 \%$ of the pressure variance at $\mathrm{O}_{91}$ and $\mathrm{O}_{246}$, respectively). Average and median values were then calculated for each bin, giving the averaged/median normalized dissolved $\mathrm{CH}_{4}$ value (standard score) for each current velocity defined data portion as a function of the M2 tidal cycle (Figure 4). This partial decoupling of variability in hydrostatic pressure and current direction was possible since the bottom water current and hydrostatic pressure changes had different dominant tidal constituents, i.e. the current was mainly dominated by the diurnal K1 constituent ( $\sim 23.91$ hour period), while the M2 tide is semi-diurnal (12.42 hour period).

A strong effect of the hydrostatic pressure on local seepage should elevate z-scores at decreasing pressure (from 0 to 6.2 hours, i.e. in the right half of Figure 4), which we observe at both observatories. However, we observe stronger peaks at increasing hydrostatic pressure ( -3 hours) at site $\mathrm{O}_{91}$ and at the $\mathrm{M} 2$ peak ( 0 hours) at site $\mathrm{O}_{246}$, which contradicts this hypothesis. This does not mean that there is no effect of hydrostatic pressure changes, but rather that the seepage in the area is widespread at both falling and rising tide conditions. The high variability caused by the strong effect of current direction also makes it particularly challenging to detect moderate changes in seepage intensity. 


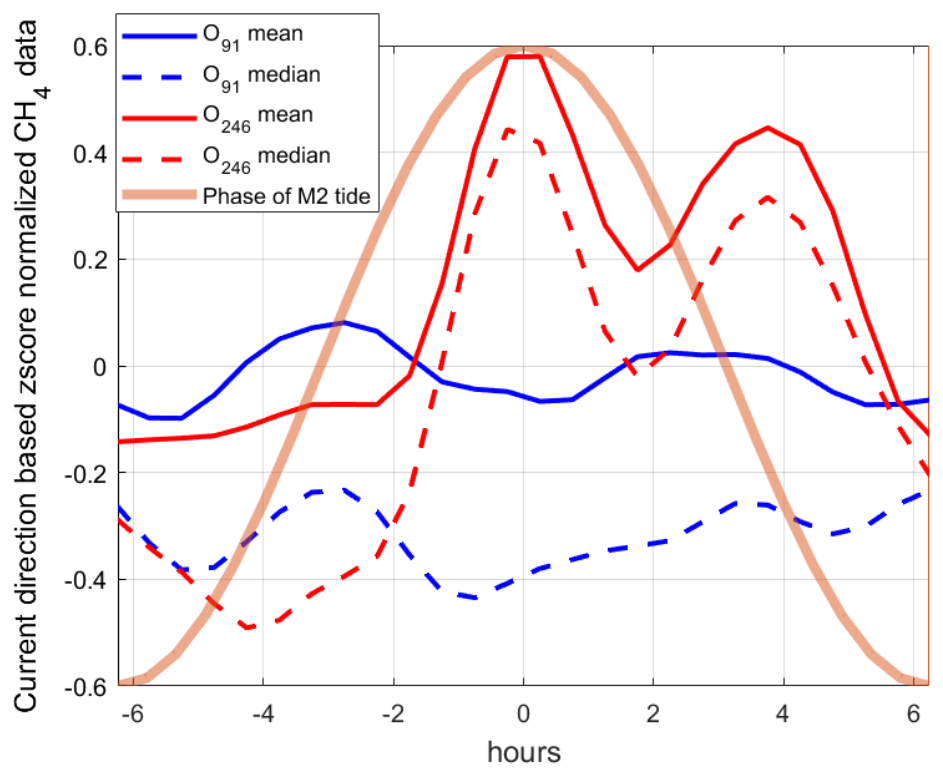

Figure 4. Median and averaged z-scores of $\mathrm{CH}_{4}$ binned according to bottom water current direction according to where the data were sampled on the phase of the M2 pressure tide.

\subsection{Bottom water temperature}

Bottom water temperature can affect $\mathrm{CH}_{4}$ release by altering hydrate stability and $\mathrm{CH}_{4}$ solubility in pore water and water column (Sloan, 1998; Jansson et al., 2019a). Seasonal $\mathrm{CH}_{4}$ release variability resulting from temperature variations in the bottom water has been linked to migration of the GHSZ and hydrate dissociation further offshore at $\sim 390 \mathrm{~m}$ water depth (Berndt et al., 2014; Ferré et al., 2020). Our observatories were deployed in areas too shallow for gas hydrate to form. However, inversely varying seepage intensity between seepage at the GHSZ depth $(390 \mathrm{~m})$ and site $\mathrm{O}_{246}$ can suggest that these areas are fed by the same hydrocarbon source and that hydrates seasonally block the lateral pathways between these seep sites (VelosoAlarcón et al., 2019). This is in agreement with the observed long-term ( $\sim 3$ months) negative correlation between bottom water temperature and dissolved $\mathrm{CH}_{4}$ at site $\mathrm{O}_{246}(\mathrm{R}=-0.31)$. It should be noted that the same relationship is observed at $\mathrm{O}_{91}$, however no geophysical data are available from this area due to the shallow depth.

Tidal pressure variations can affect $\mathrm{CH}_{4}$ release via pore water solubility (Sect. 4.2), but on longer timescales, $\mathrm{CH}_{4}$ solubility is almost exclusively a function of water temperature. Higher $\mathrm{CH}_{4}$ solubility implies more $\mathrm{CH}_{4}$ dissolved in pore water and within bubble streams, potentially increasing the amount of $\mathrm{CH}_{4}$ dissolved in bottom water. A small but significant $(\mathrm{R}=0.33)$ positive correlation between $\mathrm{CH}_{4}$ solubility and concentration at site $\mathrm{O}_{246}$, and site $\mathrm{O}_{91}$ (considering the same time period, i.e. until 3 October in 2015), could indicate such an effect. This is also an alternative explanation for the negative correlation between temperature and $\mathrm{CH}_{4}$ concentration at site $\mathrm{O}_{246}$. 
https://doi.org/10.5194/os-2021-85

Preprint. Discussion started: 13 September 2021

\subsection{Pore water seepage}

Short-term temperature increase further offshore $\left(390 \mathrm{~m}\right.$ depth) has been linked with release of warm, $\mathrm{CH}_{4}$ rich fluids from the sediments triggered by short duration seismic events (Franek et al., 2017). This means that increased $\mathrm{CH}_{4}$ concentration should be accompanied by increased water temperature and reduced salinity due to admixture of warmer, less saline pore water. We compared short-term anomalies (i.e., deviations from daily means) in these three variables in the 24-hour data sets at both seep sites, but found no corroborating evidence for this hypothesis. Instead, the covariance between current velocity and temperature and salinity anomalies indicates that short-term variability is mainly caused by cross-shelf exchange of AW in the WSC and ArW in the CC due to eddies (Hattermann et al., 2016). It also indicates that $\mathrm{CH}_{4}$ release comes mainly from bubble dissolution and not pore water seepage.

\subsection{Seasonal variation of $\mathrm{CH}_{4}$ distribution at site $\mathrm{O}_{91}$}

Low atmospheric release of $\mathrm{CH}_{4}$ from $\mathrm{O}_{91}$ during summer, despite high seabed influx, has been explained by suppression of vertical mixing by strong stratification (Myhre et al., 2016a) or absence of mechanical forcing such as wind stress (Silyakova et al., 2020). However, in fall and winter, the water column offshore PKF is expected to have more horizontal and vertical mixing due to weaker stratification from cooling or sea ice formation (Tverberg et al., 2014), baroclinic instability in the frontal structures of the WSC (von Appen et al., 2016; Hattermann et al., 2016), and more frequent storms (Nilsen et al., 2016).

We expect lower $\mathrm{CH}_{4}$ variability and lower $\mathrm{CH}_{4}$ concentration during periods of high mixing and dispersion, due to weaker horizontal and vertical gradients and more efficient dispersion of $\mathrm{CH}_{4}$ away from sources. We use three sets of parameters to evaluate long term changes in the amount of mixing in the water column (see Appendix E): i) the 4-week averaged bulk velocity shear $\left(\mathrm{S}_{b}\right)$, ii) the two dimensional correlation between wind stress and current velocity $\left(\mathrm{R}_{W C}\right)$, and iii) the number of stormy days defined by persistent winds $>11 \mathrm{~m} / \mathrm{s}$ lasting longer than 6 hours (Figure 5). Calm weather, low $\mathrm{S}_{b}$ and $\mathrm{R}_{W C}$ until mid-September 2015 indicate a stable water column with limited mixing in the bottom waters. From mid-September, $\mathbf{S}_{b}$ increased and stayed high until mid-November, together with a gradual increase in $\mathrm{R}_{W C}$ which can be attributed to a gradual breakdown of stratification and increasing number of storm events (Figure $5 \mathrm{a}) . \mathrm{R}_{W C}$ remained high $\left(\mathrm{R}_{W C}>0.5\right.$ at $60 \mathrm{~m}$ depth) until March 2016, indicating significant effect of wind forcing in the water column. From March until observatory retrieval, $\mathrm{R}_{W C}$ decreased to $<0.2$ below $50 \mathrm{~m}$ depth while $\mathrm{S}_{b}$ increased below $60 \mathrm{~m}$ depth, indicating available energy for mixing in the bottom waters.

We quantified $\mathrm{CH}_{4}$ variability during the 24-hour measurements using the Median Absolute Deviation (MAD) and used the median as a measure of the amount of dissolved $\mathrm{CH}_{4}$. The three 24-hour periods collected during the calmer period prior to mid-September had high median concentration $(>300 \mathrm{nmol} \mathrm{L}-1)$ and the overall highest variability (MAD $>160 \mathrm{nmol}$ $\mathrm{L}-1$ ), as expected for low mixing conditions (Figures $5 \mathrm{~b}$ and 5c). From mid-September until the end of March (i.e. fall/winter season), the 24-hour $\mathrm{CH}_{4}$ concentration time-series had generally lower MAD and median concentration. In this period, $\mathrm{CH}_{4}$ variability and median also showed a good statistical relationship with the 5 days accumulated wind stress ( $\mathrm{R}=-0.82$ for MAD and $\mathrm{R}=-0.61$ for median concentration), indicating that wind forcing has a deep impact on mixing and redistribution of $\mathrm{CH}_{4}$ 


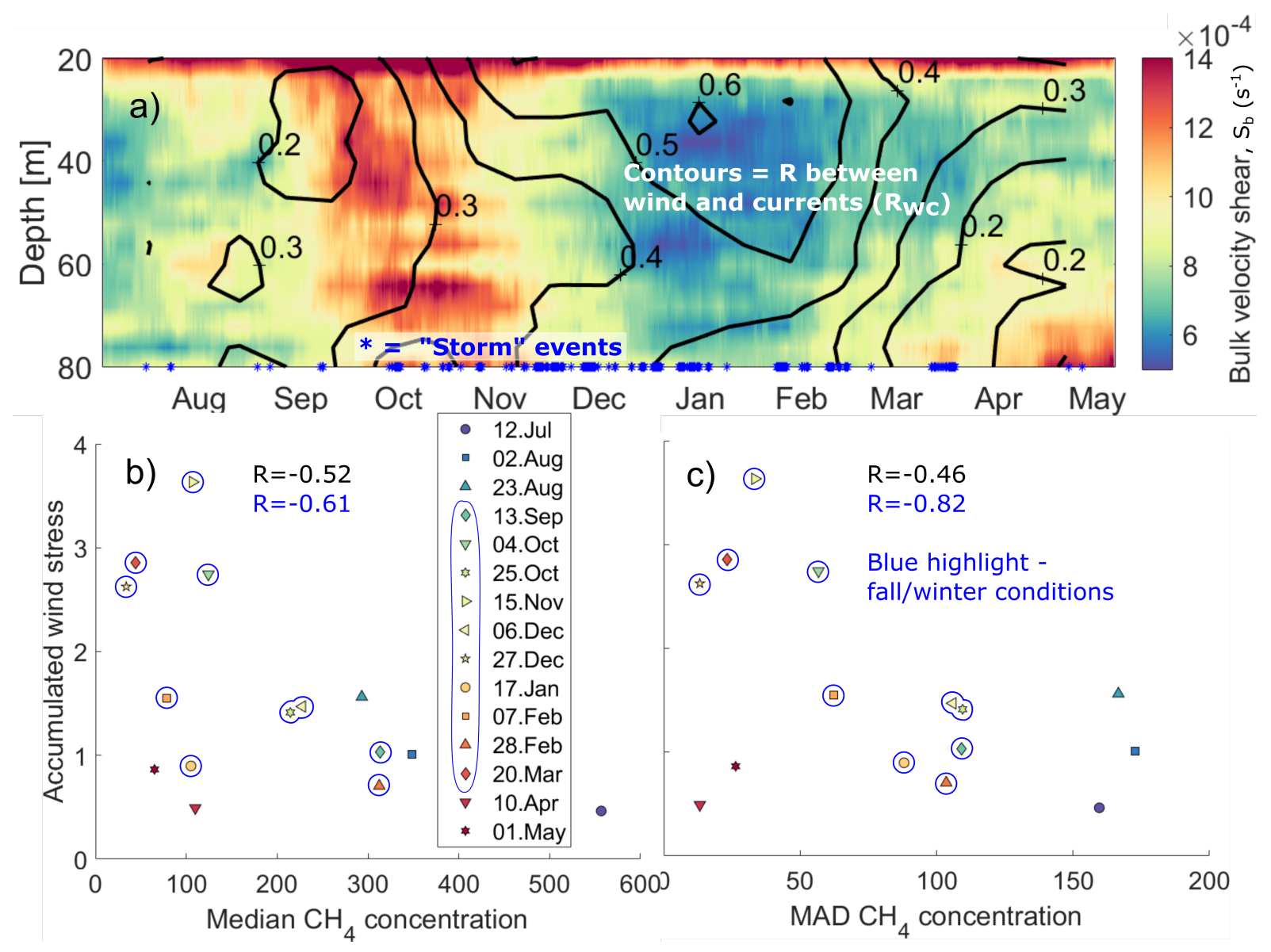

Figure 5. a) Bulk velocity shear ( $\Delta \mathrm{H}=8$ meter) and two dimensional correlation with wind stress (contours). Relationship between 5 days accumulated wind stress and median (b) as well as median absolute deviation (c) of $\mathrm{CH}_{4}$ concentration for 24 hour data periods. Persistent wind events with more than $10 \mathrm{~m} \mathrm{~s}^{-1}$ winds in periods over 6 hours are indicated with blue stars along the $\mathrm{x}$-axis of diagram a). Blue highlights fall/winter water column conditions as described in the text.

in the water column (which also fits well with a high $\mathrm{R}_{W C}$ ). The two last 24-hour $\mathrm{CH}_{4}$ time series (10 April and 1 May) had low median concentration, which could be explained by the absence of stratification (Silyakova et al., 2020) and generation of mixing from the observed increase in $\mathrm{S}_{b}$.

Accumulated wind stress, $\mathrm{S}_{b}$ and $\mathrm{R}_{W C}$ are only limited indicators on water column dispersion and mixing. Nonetheless, the relationship between these parameters and the MAD and medians of the 24 hour period $\mathrm{CH}_{4}$ time series gives a good indication on the seasonal cycle of distribution and vertical transport of $\mathrm{CH}_{4}$ : strong stratification, less wind forcing and eddy activity in summer limits mixing and prevents $\mathrm{CH}_{4}$ from reaching the atmosphere. However, in fall and winter, reduced stratification makes the water column more prone to mixing and distribution of $\mathrm{CH}_{4}$ seems to be strongly linked with wind forcing from September to April. 


\section{Conclusions}

Time-series of dissolved $\mathrm{CH}_{4}$ at both lander locations show considerably higher $\mathrm{CH}_{4}$ concentrations (up to $1789 \mathrm{nmol} \mathrm{L}^{-1}$ at $\mathrm{O}_{91}$ and $2727 \mathrm{nmol} \mathrm{L}^{-1}$ at $\mathrm{O}_{246}$ ) than previously estimated from ship-based water sampling surveys (maximum of 482 near $\mathrm{O}_{91}$ and of 564 near $\mathrm{O}_{246}$ ). The time-series also uncover high $\mathrm{CH}_{4}$ variability (up to $\sim 1000 \mathrm{nmol} \mathrm{L}{ }^{-1}$ ) within short timescales ( $<24$ hours) and a heterogeneous $\mathrm{CH}_{4}$ distribution, highlighting the uncertainty of flux/inventory estimates based on interpolation/extrapolation techniques where even/linear $\mathrm{CH}_{4}$ distribution is assumed. Variability can be linked to directional ocean current variations occurring at tidal time-scales which shows the importance of taking the current direction and seep locations into account when interpreting intense seep site observations. The persistent relationship between current direction and seep configuration shows that there is no significant change in seepage through the year.

We did not observed a direct effect of tidal pressure variations on $\mathrm{CH}_{4}$ release, but this could be hidden by the strong effect of variations in current direction. A negative (long-term) correlation between temperature and dissolved $\mathrm{CH}_{4}$ at $\mathrm{O}_{246}$ is in agreement with the hypothesized seasonal blocking of lateral $\mathrm{CH}_{4}$ pathways in the sediments (Veloso-Alarcón et al., 2019) but could also be explained by increased $\mathrm{CH}_{4}$ solubility in the water column.

Short-term, small-scale variations in temperature and salinity were not linked with increased amounts of dissolved $\mathrm{CH}_{4}$, but rather with cross-frontal exchange of water masses due to eddies.

We observed a seasonal cycle in the characteristics of the 24-hour time-series which fits with seasonal changes in dispersion and mixing characteristics of the water column. Higher $\mathrm{CH}_{4}$ concentration and variability in early fall, when stratification was strong, was followed by lower median concentrations and variability in late fall/winter when the water column was more affected by mixing. In late fall/winter, wind forcing was statistically coupled to the concentration and variability of $\mathrm{CH}_{4}$, probably due to weaker water column stratification.

When estimating the atmospheric impact of a particular $\mathrm{CH}_{4}$ source based on sparse measurements, it is crucial to have some constraint on the temporal and spatial variability. These constraints can either be direct knowledge about variability itself or how inventory and fluxes are affected by related physical and/or chemical parameters. We observed considerable temporal and spatial variability at the two seep sites which need to be taken into account to obtain meaningful estimates of $\mathrm{CH}_{4}$ fluxes or inventories. That no strong direct link was found with other oceanographic parameters illustrate the non-linearity of the system, making careful interpretation of measurements important. Based on our observations, we suggest that uncertainties in $\mathrm{CH}_{4}$ inventory and seep estimates can be mitigated by taking the local seep configuration, ocean currents and mixing rates into account, avoid linear interpolation techniques (or using more suitable distribution assumptions), and employ autonomous instrumentation capable of resolving the steep horizontal gradients in dissolved $\mathrm{CH}_{4}$. This, alongside direct measurements of seepage by e.g., acoustic instrumentation, can help constrain future estimates of $\mathrm{CH}_{4}$ flux to the atmosphere from seabed seepage. 
https://doi.org/10.5194/os-2021-85

Preprint. Discussion started: 13 September 2021

(C) Author(s) 2021. CC BY 4.0 License.

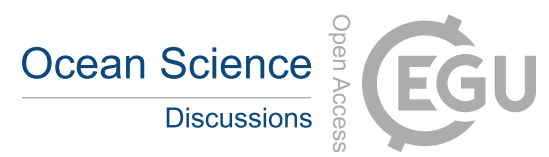

330 Code and data availability. All data presented in this paper can be obtained upon request to the authors and will also be made available in the platform Open research Data at the University of Troms $\varnothing$ - The Arctic University of Norway (https://dataverse.no/dataverse/uit). All computer code being used can be obtained upon request to the corresponding author 
https://doi.org/10.5194/os-2021-85

Preprint. Discussion started: 13 September 2021

(c) Author(s) 2021. CC BY 4.0 License.

(c) (i)

\section{Appendix A: The K-Lander}

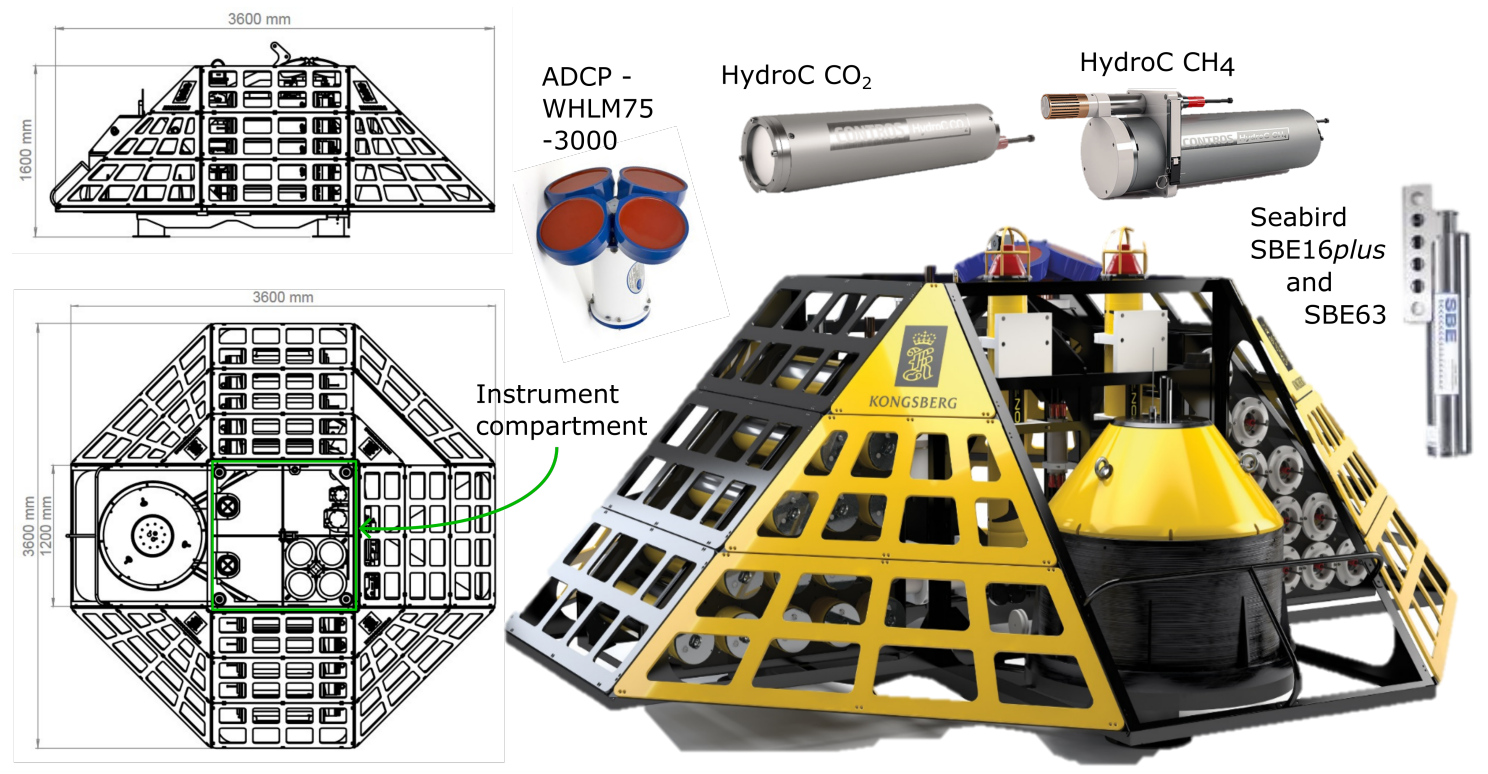

Figure A1. The K-Lander is a $1.6 \mathrm{~m}$ high and $3.6 \mathrm{~m}$ wide trawl-proof stainless-steel frame with multiple instrument mounts and batteries. Side panels are perforated to allow unobstructed water flow to the instruments inside the structure. See Appendix B for details on instrumentation. 
https://doi.org/10.5194/os-2021-85

Preprint. Discussion started: 13 September 2021

(c) Author(s) 2021. CC BY 4.0 License.

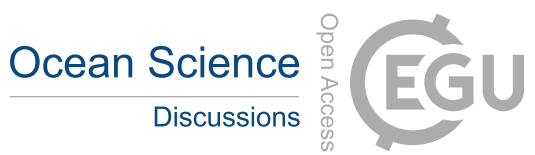

(c) ${ }_{\mathrm{Bv}}$

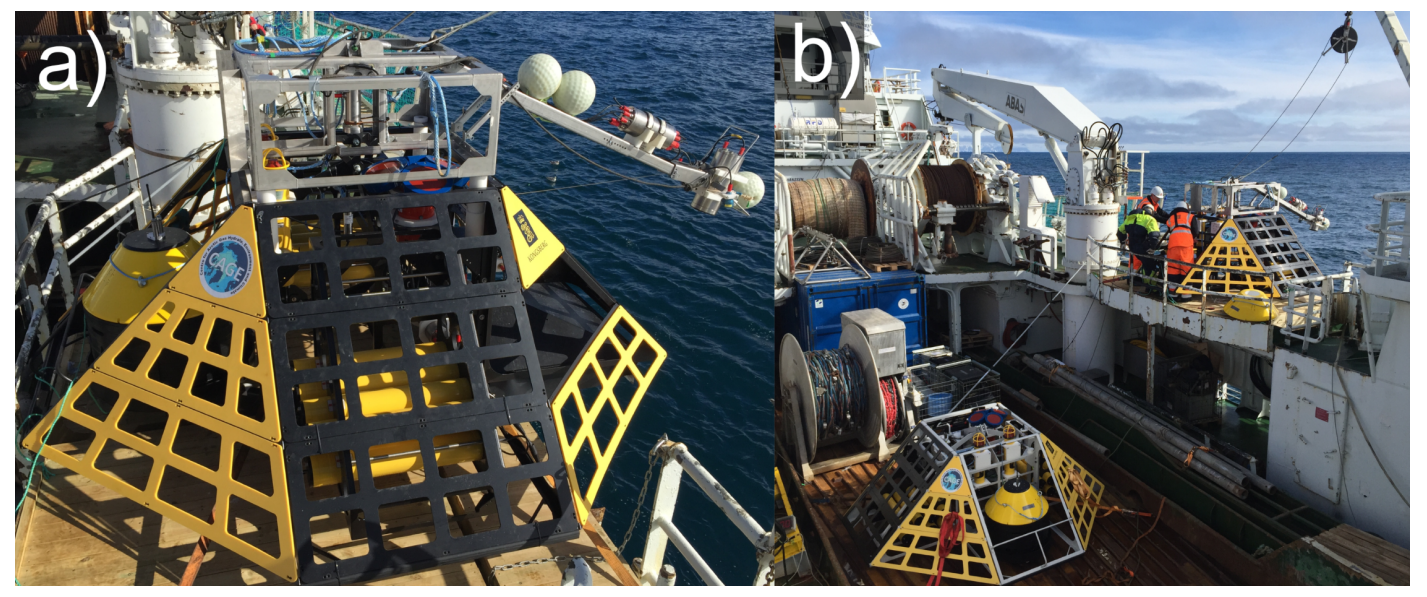

Figure A2. a) K-Lander during deployment with launcher mounted on top and camera system mounted on a boom for visual control of landing area. b) The two K-landers before deployment. 
https://doi.org/10.5194/os-2021-85

Preprint. Discussion started: 13 September 2021

\section{Appendix B: Measurement intervals, general post-processing and data}

The CTD/oxygen sensor and ADCP conducted measurements every 4 and 9 minutes, respectively, during the continuous monitoring of $\mathrm{CH}_{4}$ and $\mathrm{CO}_{2}$ measurements, and 21 and 29 minutes during the rest of the deployment period (see Table B1 for acronyms, description, and measurement accuracy). Salinity was measured on the practical salinity scale.

The upward mounted ADCP measured ocean currents in $1 \mathrm{~m}$ bins with a bottom $7 \mathrm{~m}$ blank distance, where the topmost $20 \%$ of the water column was disregarded due to side lobe interference. The high resolution, relatively short ensemble time (1 minute), and potential presence of $\mathrm{CH}_{4}$ bubbles in the water resulted in noisy data. We dampened the noise by first removing any data points with error velocities exceeding one short-term (1 week) standard deviation, smoothed the data using a second order Butterworth low-pass filter with a 3-hour cutoff period and a spatial (i.e. vertical) moving average filter with a $5 \mathrm{~m}$ Hann window (increasing the blank distance to 10 meter). The accuracy of the ADCP data is therefore not explicitly constrained and is based on comparing current velocity frequency spectra before and after filtering, combined with averaged error velocity of the raw data (Table B1).

Table B1. Instruments mounted on $\mathrm{O}_{91}$ and $\mathrm{O}_{246}$ (see Figure A1), measured parameters, height in meters above sea floor (masf) and stated accuracy. ADCP stands for Acoustic Doppler Current Profiler. N shows the number of data-points used for later multi-variable analysis for $\mathrm{O}_{91} / \mathrm{O}_{246}$. (*)The Contros HydroC $\mathrm{CH}_{4}$ output partial pressure from the internal gas chamber. (**)We report absolute concentration in seawater (nmol L ${ }^{-1}$ ) using Henry's law and (***) report accuracy only for response time corrected (RTC) concentration (see Appendix C) since the accuracy for untreated $\mathrm{CH}_{4}$ concentration data is ambiguous due to the slow response time.

\begin{tabular}{|c|c|c|c|c|}
\hline Instrument & Parameter(s) & masf & $\mathrm{N}$ & Accuracy \\
\hline Teledyne RDI ADCP WHLM75-3000 & Current velocity Profile & 1.6 & $17438 / 4731$ & $\sim 3 \mathrm{~cm} \mathrm{~s}^{-1}$ \\
\hline Contros HydroC $\mathrm{CH}_{4}$ & $\begin{array}{l}p \mathrm{CH}_{4} \text { (instrument output)* } \\
\mathrm{xCH}_{4}\left(\text { reported }^{* *}\right)\end{array}$ & 1.2 & $1491 / 281$ & $\sim 5-20 \%\left(\mathrm{RTC}^{* * *}\right)$ \\
\hline Contros HydroC $\mathrm{CO}_{2}$ & $p \mathrm{CO}_{2}$ & 1.2 & $1491 / 281$ & N/A (no pump) \\
\hline SeaBird SBE16plus V2 & $\begin{array}{l}\text { Conductivity/Temperature } \\
\text { /Depth }\end{array}$ & 1.2 & $29660 / 9065$ & $\begin{array}{r}0.0005 \mathrm{Sm}^{-1} / 0.005^{\circ} \mathrm{C}, \\
/ 0.02 \% \text { of range }\end{array}$ \\
\hline Seabird SBE63 oxygen optode & Dissolved Oxygen & 1.2 & $29660 / 9065$ & $3 \mu \mathrm{mol} \mathrm{kg}{ }^{-1}$ or $\pm 2 \%$ \\
\hline
\end{tabular}

Since sensors were recording at different frequencies, chronological alignment of the data was carried out by identifying nearest neighbor data points or by resampling. For correlation coefficients, histograms, and Fourier analysis, the data sets were resampled to a uniform 15 minute or 1 hour measuring interval depending on the sample frequency of the raw data, using a poly-phase anti-aliasing filter. Due to the power-cycling mode of the $\mathrm{CH}_{4}$ and $\mathrm{CO}_{2}$ sensors and differing sampling frequencies, some statistics were based on more data points than others (outlined in Table B1). Daily measurements of $\mathrm{CH}_{4} \mathrm{Were} \mathrm{excluded}$ from statistics due to the high probability of systematic errors induced by periodic diurnal effects. 
https://doi.org/10.5194/os-2021-85

Preprint. Discussion started: 13 September 2021

(C) Author(s) 2021. CC BY 4.0 License.

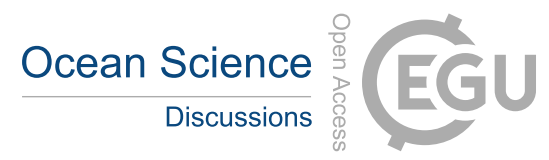

(c) (1)

Harmonic analysis of hydrostatic pressure and ocean currents was done using t_tide (see Pawlowicz et al., 2002) and the fast Fourier transform.

We calculated the rate of change (ROC) in $\mathrm{CH}_{4}$ concentration using the response time corrected $\mathrm{CH}_{4}$ data and the absolute value of the three point ( 9 minutes) finite differences to limit the effect of noise on the calculation.

The absolute concentration of $\mathrm{CH}_{4}$ in the water $(\mathrm{nmol} \mathrm{L}-1)$ was estimated from the partial pressure of $\mathrm{CH}_{4}$, pressure, temperature, and salinity, using Henry's law and Henry constants obtained from Harvey et al., (1996) and practical molar volume and gamma term from Duan \& Mao et al., (2006). 
https://doi.org/10.5194/os-2021-85

Preprint. Discussion started: 13 September 2021

(c) Author(s) 2021. CC BY 4.0 License.

(c) (i)

\section{Appendix C: Response time correction}

In the Contros HydroC $\mathrm{CH}_{4}$ and $\mathrm{CO}_{2}$ sensors, dissolved gases diffuse through a hydrophobic membrane into a gas chamber and equilibrate with the ambient environment. This results in a slow response time and poor representation of the rapid changes in $\mathrm{CH}_{4}$ as we expected in our study area (Gentz et al., (2013) and Myhre et al., (2016)). We therefore performed a response time correction of the dissolved $\mathrm{CH}_{4}$ data following the methodology presented in Dølven et al. (In prep) Briefly, this method deconvolves slow sensor response using statistical inverse theory assuming that changes occur with time-step $\Delta t$, determined based on domain-specific knowledge or L-curve analysis. The $\mathrm{CO}_{2}$ sensors had a faulty pump, which ambiguously increased the response time of the sensors making response time correction impossible.

The response time correction was performed for each period individually ( 1 hour and 24 hour, i.e. 377 periods), using the stated measurement accuracy of the instrument ( $2 \mu \mathrm{Atm}$ or 3\% of measured value, whichever is higher) as input uncertainty. We first identified the ideal $\Delta \mathrm{t}$ according to the maximum curvature point in the L-curves of the 24 hour measurement periods. These varied slightly between each measurement period, but averaging close to $180 \mathrm{~s}$ (176.4 s). To keep the same measuring interval for all the $\mathrm{CH}_{4}$ data, we therefore corrected all the data with a specified $\Delta \mathrm{t}$ of $180 \mathrm{~s}$, which falls well within the bend of the L-curve and should therefore safeguard a good balance between noise and model error (Figure C1). The uncertainty estimate varied depending on the amount of $\mathrm{CH}_{4}$ measured by the laser spectrometry in the measurement chamber of the instrument and ranged from 4 to $80 \mathrm{nmol} \mathrm{L}^{-1}$ (95\% confidence, high for high concentrations in measurement chamber and vice versa) or $\sim 5-20 \%$ of response time corrected value.

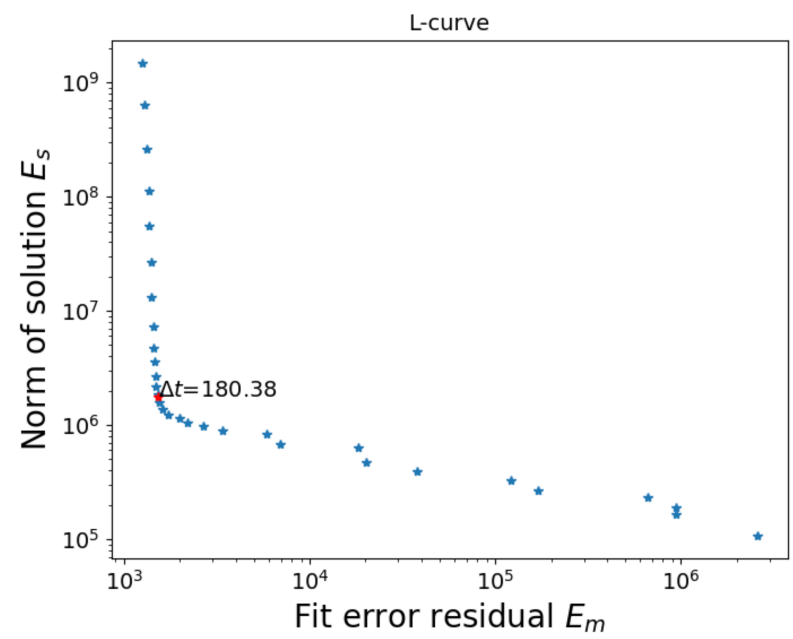

Figure C1. L-curve for response time correction of $\mathrm{CH}_{4}$ data showing the location of the chosen $\Delta t$ (180 s) for $6 \mathrm{May}$ at $\mathrm{O} 91$. 
https://doi.org/10.5194/os-2021-85

Preprint. Discussion started: 13 September 2021

(C) Author(s) 2021. CC BY 4.0 License.

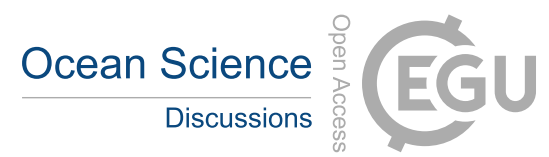

Appendix D: 24-hour measurements of $\mathrm{CH}_{4}$ 
https://doi.org/10.5194/os-2021-85

Preprint. Discussion started: 13 September 2021

(c) Author(s) 2021. CC BY 4.0 License.
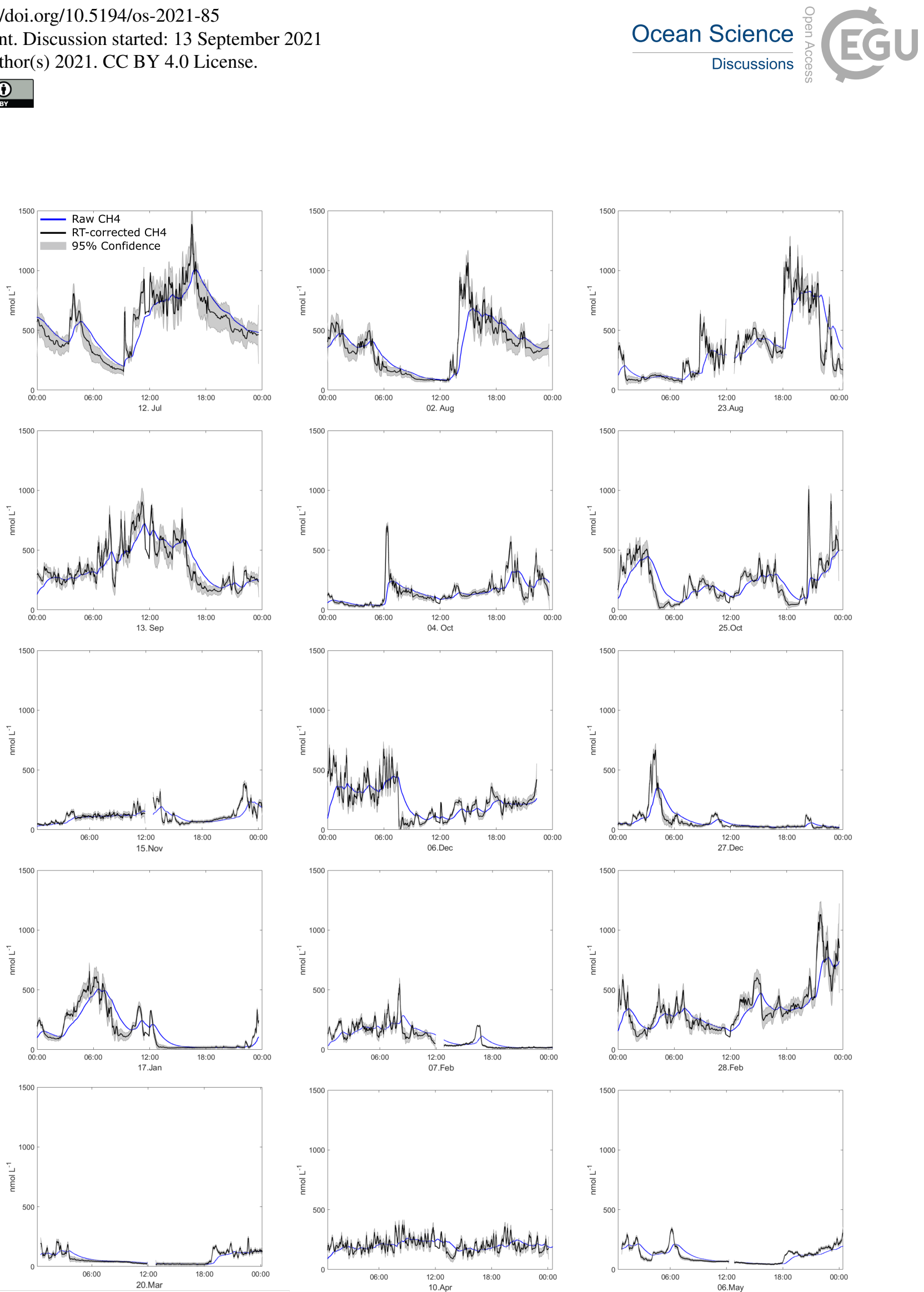

Figure D1. All 24 hour periods of $\mathrm{CH}_{4}$ concentration at $\mathrm{O}_{91}$ with response time corrected data (black) with uncertainty estimate (grey shade, $95 \%$ confidence) and raw data (blue) from $\mathrm{O}_{91}$. 
https://doi.org/10.5194/os-2021-85

Preprint. Discussion started: 13 September 2021

(C) Author(s) 2021. CC BY 4.0 License.

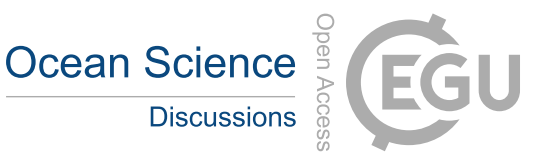

(c) (1)
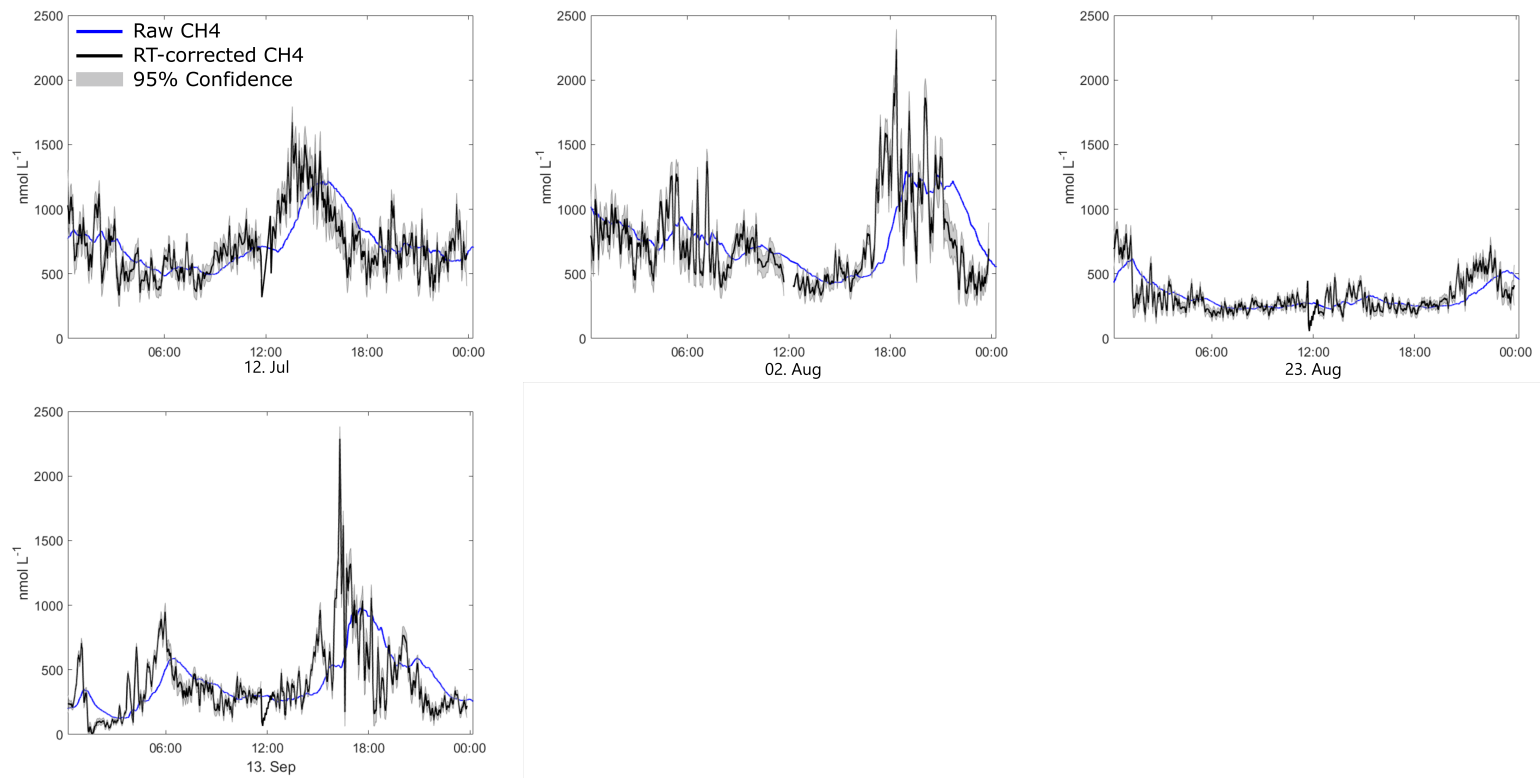

Figure D2. All 24 hour periods of $\mathrm{CH}_{4}$ concentration at $\mathrm{O}_{246}$ with response time corrected data (black) with uncertainty estimate (grey shade, 95\% confidence) and raw data (blue) from $\mathrm{O}_{246}$. 
https://doi.org/10.5194/os-2021-85

Preprint. Discussion started: 13 September 2021

(c) Author(s) 2021. CC BY 4.0 License.

\section{Appendix E: Bulk velocity shear and wind stress correlation}

We calculated bulk wind stress using 10 meter above sea level ERA-interim re-analysis wind data (Dee et al., 2011) and Large $\&$ Pond (1981). Water column bulk velocity shear $S_{b}$ (see e.g. Lincoln et al., 2016) was calculated as

$S_{b}^{2}=\left(\frac{u_{u}-u_{l}}{h_{\text {diff }}}\right)^{2}+\left(\frac{v_{u}-v_{l}}{h_{\text {diff }}}\right)^{2}$

where $u_{u}, u_{l}, v_{u}, v_{l}$ refer to the easterly and northerly ADCP velocity components in the upper (subscript u) and lower (subscript 1) layer and $h_{\text {diff }}$ the vertical distance between layers. The direct effect of wind stress is usually confined to surface water, although indirect effects such as Ekman transport/overturning and the formation of eddies can facilitate currents and mixing at deeper depths (Cushman-Roisin and Beckers, 2011). The two-dimensional correlation coefficient $\mathrm{R}_{W C}$ between the wind and ocean currents was calculated using Kundu, (1976) and the complex representations $\tau_{c}$ and $u_{c}$ of the wind stress and de-tided current velocity vectors:

$\mathrm{R}_{W C}=\frac{\left\langle\tau_{c}^{*} u_{c}\right\rangle}{\left\langle\tau_{c}^{*} \tau_{c}\right\rangle^{\frac{1}{2}}\left\langle u_{c}^{*} u_{c}\right\rangle^{\frac{1}{2}}}$

where $\langle.$.$\rangle gives the normalized inner product of the vectors and * annotates the complex conjugate. We allow time-lags up$ to 15 hours to account for the gradual and indirect effects of wind stress on the ocean currents. Both properties were estimated throughout the valid current velocity profile, but only down to $80 \mathrm{~m}$ depth due to the $8 \mathrm{~m}$ vertical distance between the defined layers used in the bulk velocity shear calculation. 
https://doi.org/10.5194/os-2021-85

Preprint. Discussion started: 13 September 2021

(C) Author(s) 2021. CC BY 4.0 License.

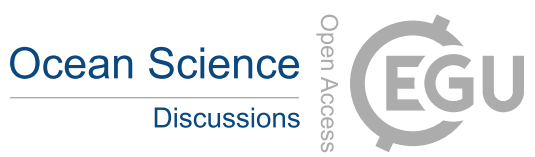

(c) (1)

Author contributions. Conceptualization: KOD,BF,AS,PL,PJ. Data curation: KOD,BF,MM. Formal Analysis: KOD,BF,MM. Funding acquisition: BF. Investigation: KOD, BF, AS. Methodology: KOD,BF. Project administration: BF, AS. Resources: BF. Software: KOD. Supervision: BF. Validation: n/a. Visualization: KOD,MM. Writing - original draft preparation: KOD. Writing - review \& editing: KOD, BF, AS, PL, PJ, MM.

Competing interests. The authors declare that they have no conflict of interest.

Acknowledgements. We thank the crew of R/V Helmer Hanssen during the deployment (CAGE 15-3) and recovery (CAGE 16-4) cruises. This study is a part of CAGE (Centre for Arctic Gas Hydrate, Environment and Climate), Norwegian Research Council grant no. 223259). We thank Nicholas Warner for proofreading the article. 
https://doi.org/10.5194/os-2021-85

Preprint. Discussion started: 13 September 2021

\section{References}

Berchet, A., Bousquet, P., Pison, I., Locatelli, R., Chevallier, F., Paris, J.-D., Dlugokencky, E. J., Laurila, T., Hatakka, J., Viisanen, Y., Worthy, D. E. J., Nisbet, E., Fisher, R., France, J., Lowry, D., Ivakhov, V., and Hermansen, O.: Atmospheric constraints on the methane emissions from the East Siberian Shelf, Atmospheric Chemistry and Physics, 16, 4147-4157, https://doi.org/10.5194/acp-16-4147-2016, 2016.

Berndt, C., Feseker, T., Treude, T., Krastel, S., Liebetrau, V., Niemann, H., Bertics, V. J., Dumke, I., Dünnbier, K., Ferré, B., Graves, C., Gross, F., Hissmann, K., Hühnerbach, V., Krause, S., Lieser, K., Schauer, J., and Steinle, L.: Temporal Constraints on Hydrate-Controlled Methane Seepage off Svalbard, Science, 343, 284-287, https://doi.org/10.1126/science.1246298, 2014.

Beszczynska-Möller, A., Fahrbach, E., Schauer, U., and Hansen, E.: Variability in Atlantic water temperature and transport at the entrance to the Arctic Ocean, 1997-2010, ICES Journal of Marine Science, 69, 852-863, https://doi.org/10.1093/icesjms/fss056, 2012.

Braga, R., Iglesias, R., Romio, C., Praeg, D., Miller, D., Viana, A., and Ketzer, J.: Modelling methane hydrate stability changes and gas release due to seasonal oscillations in bottom water temperatures on the Rio Grande cone, offshore southern Brazil, Marine and Petroleum Geology, 112, 104 071, https://doi.org/https://doi.org/10.1016/j.marpetgeo.2019.104071, 2020.

Canning, A., Fietzek, P., Rehder, G., and Körtzinger, A.: Technical note: Seamless gas measurements across the land-ocean aquatic continuum - corrections and evaluation of sensor data for $\mathrm{CO} 2, \mathrm{CH} 4$ and $\mathrm{O} 2$ from field deployments in contrasting environments, Biogeosciences, 18, 1351-1373, https://doi.org/10.5194/bg-18-1351-2021, 2021.

Cottier, F., Nilsen, F., Inall, M. E., Gerland, S., Tverberg, V., and Svendsen, H.: Wintertime warming of an Arctic shelf in response to large-scale atmospheric circulation, Geophysical Research Letters, 34, https://doi.org/10.1029/2007GL029948, 2007.

Cushman-Roisin, B. and Beckers, J.-M.: Introduction to Geophysical Fluid Dynamics, vol. 101, Elsevier Academic Press, second edi edn., 2011.

Dee, D., Uppala, S., Simmons, A., Berrisford, P., Poli, P., Kobayashi, S., Andrae, U., Balmaseda, M., Balsamo, G., Bauer, P., Bechtold, P., Beljaars, A., van de Berg, L., Bidlot, J., Bormann, N., Delsol, C., Dragani, R., Fuentes, M., Geer, A., Haimberger, L., Healy, S., Hersbach, H., Hólm, E., Isaksen, L., Kållberg, P., Köhler, M., Matricardi, M., McNally, A., Monge-Sanz, B., Morcrette, J.-J., Park, B.-K., Peubey, C., de Rosnay, P., Tavolato, C., Thépaut, J.-N., and Vitart, F.: The ERA-Interim reanalysis: configuration and performance of the data assimilation system, Quarterly Journal of the Royal Meteorological Society, 137, 553-597, https://doi.org/10.1002/qj.828, 2011.

Dølven, K. O., Vierinen, J., Grilli, R., Trieste, J., and Férré, B.: Response time correction of slow response sensor data by deconvolution of the growth-law equation, In prep.

Duan, Z. and Mao, S.: A thermodynamic model for calculating methane solubility, density and gas phase composition of methanebearing aqueous fluids from 273 to $523 \mathrm{~K}$ and from 1 to 2000 bar, Geochimica et Cosmochimica Acta, 70, 3369-3386, https://doi.org/10.1016/j.gca.2006.03.018, 2006.

Etiope, G., Ciotoli, G., Schwietzke, S., and Schoell, M.: Gridded maps of geological methane emissions and their isotopic signature, Earth System Science Data, 11, 1-22, https://doi.org/10.5194/essd-11-1-2019, 2019.

Ferré, B., Mienert, J., and Feseker, T.: Ocean temperature variability for the past 60 years on the Norwegian-Svalbard margin influences gas hydrate stability on human time scales, Journal of Geophysical Research: Oceans, 117, https://doi.org/10.1029/2012JC008300, 2012.

Ferré, B., Jansson, P., Moser, M., Portnov, A., Graves, C., Panieri, G., Gründger, F., Berndt, C., Lehmann, M., and Niemann, H.: Reduced methane seepage from Arctic sediments during cold bottom-water conditions, Nature Geoscience, 13, 144-148, https://doi.org/10.1038/s41561-019-0515-3, 2020. 
https://doi.org/10.5194/os-2021-85

Preprint. Discussion started: 13 September 2021

(c) Author(s) 2021. CC BY 4.0 License.

(c) (i)

Franek, P., Plaza-Faverola, A., Mienert, J., Buenz, S., Ferré, B., and Hubbard, A.: Microseismicity Linked to Gas Migration and Leakage on the Western Svalbard Shelf, Geochemistry, Geophysics, Geosystems, 18, 4623-4645, https://doi.org/10.1002/2017GC007107, 2017.

Gentz, T., Damm, E., von Deimling, J. S., Mau, S., McGinnis, D. F., and Schlüter, M.: A water column study of methane around gas flares located at the West Spitsbergen continental margin, Continental Shelf Research, 72, 107-118, https://doi.org/10.1016/j.csr.2013.07.013, 2014.

Gerkema, T.: Tidal Constituents and the Harmonic Method, p. 60-86, Cambridge University Press, https://doi.org/10.1017/9781316998793.005, 2019.

Graves, C. A., Lea, S., Gregor, R., Niemann, H., Connely, D. P., Lowry, D., Fisher, R. E., Stott, A. W., Sahling, H., and James, R. H.: Fluxes and fate of dissolved methane released at the seafloor at the landward limit of the gas hydrate stability zone offshore western Svalbard, Journal of Geophysical Research: Oceans, 120, 6185-6201, https://doi.org/10.1002/2015JC011084, 2015.

Hanson, R. S. and Hanson, T. E.: Methanotrophic bacteria., Microbiological Reviews, I, 439-471, 1996.

Harvey, A. H.: Semiempirical correlation for Henry's constants over large temperature ranges, AIChE Journal, 42, 1491-1494, https://doi.org/10.1002/aic.690420531, 1996.

Hattermann, T., Erik, I. P., Wilken Jon, A., Jon, A., and Arild, S.: Eddy-driven recirculation of Atlantic Water in Fram Strait, Geophysical Research Letters, 43, 3406-3414, https://doi.org/10.1002/2016GL068323, 2016.

Hopkins, T. S.: The GIN Sea-A synthesis of its physical oceanography and literature review 1972-1985, Earth-Science Reviews, 30, 175318, https://doi.org/https://doi.org/10.1016/0012-8252(91)90001-V, 1991.

Jansson, P., Ferré, B., Silyakova, A., Dølven, K. O., and Omstedt, A.: A new numerical model for understanding free and dissolved gas progression toward the atmosphere in aquatic methane seepage systems, Limnology and Oceanography: Methods, 17, 223-239, https://doi.org/10.1002/lom3.10307, 2019a.

Jansson, P., Triest, J., Grilli, R., Ferré, B., Silyakova, A., Mienert, J., and Chappellaz, J.: High-resolution underwater laser spectrometer sensing provides new insights into methane distribution at an Arctic seepage site, Ocean Science, 15, 1055-1069, https://doi.org/10.5194/os15-1055-2019, 2019b.

Kossel, E., Bigalke, N., Piñero, E., and Haeckel, M.: The SUGAR Toolbox, https://doi.org/10.1594/PANGAEA.816333, 2013.

Kundu, P. K.: Ekman Veering Observed near the Ocean Bottom, Journal of Physical Oceanography, 6, 238-242, https://doi.org/10.1175/15200485(1976)006<0238:EVONTO>2.0.CO;2, 1976.

Large W. G. and Pond S.: Open Ocean Momentum Flux Measurements in Moderate to Strong Winds, Journal of Physical Oceanography, 11, 324-336, https://doi.org/10.1175/1520-0485(1981)011<0324:OOMFMI>2.0.CO;2, 1981.

Lincoln, B. J., Rippeth, T. P., and Simpson, J. H.: Surface mixed layer deepening through wind shear alignment in a seasonally stratified shallow sea, Journal of Geophysical Research: Oceans, 121, 6021-6034, https://doi.org/https://doi.org/10.1002/2015JC011382, 2016.

Linke, P., Sommer, S., Rovelli, L., and McGinnis, D. F.: Physical limitations of dissolved methane fluxes: The role of bottom-boundary layer processes, Marine Geology, 272, 209-222, https://doi.org/10.1016/j.margeo.2009.03.020, 2009.

Mau, S., Romer, M., Torres, M. E., Bussmann, I., Pape, T., Damm, E., Geprags, P., Wintersteller, P., Hsu, C.-W., Loher, M., and Bohrmann, G.: Widespread methane seepage along the continental margin off Svalbard - from Bjørnøya to Kongsfjorden, Scientific Reports, 7, 42 997, https://doi.org/10.1038/srep42997, 2017.

McDougall, T. J. and Barker, P. M.: Getting started with TEOS-10 and the Gibbs Seawater (GSW) Oceanographic Toolbox, SCOR/IAPSO WG127, p. 22pp, 2011. 
https://doi.org/10.5194/os-2021-85

Preprint. Discussion started: 13 September 2021

(c) Author(s) 2021. CC BY 4.0 License.

McGinnis, D. F., Greinert, J., Artemov, Y., Beaubien, S. E., and Wüest, A.: Fate of rising methane bubbles in stratified waters: How much methane reaches the atmosphere?, Journal of Geophysical Research: Oceans, 111, https://doi.org/10.1029/2005JC003183, 2006.

Myhre, C. L., Ferré, B., Platt, S. M., Silyakova, A., Hermansen, O., Allen, G., Pisso, I., Schmidbauer, N., Stohl, A., Pitt, J., Jansson, P., Greinert, J., Percival, C., Fjaeraa, A. M., O’Shea, S. J., Gallagher, M., Le Breton, M., Bower, K. N., Bauguitte, S. J. B., Dalsøren, S., Vadakkepuliyambatta, S., Fisher, R. E., Nisbet, E. G., Lowry, D., Myhre, G., Pyle, J. A., Cain, M., and Mienert, J.: Extensive release of methane from Arctic seabed west of Svalbard during summer 2014 does not influence the atmosphere, Geophysical Research Letters, 43 , 4624-4631, https://doi.org/10.1002/2016GL068999, 2016a.

Myhre, C. L., Hermansen, O., Fiebig, M., Lunder, C., Fjæraa, A. M., Svendby, T., Platt, M., Hansen, G., Scmidbauer, N., and T., K.: Monitoring of greenhouse gases and aerosols at Svalbard and Birkenes in 2015 - Annual report, NILU report, 31/2016, 2016b.

Nilsen, F., Skogseth, R., Vaardal-Lunde, J., and Inall, M.: A Simple Shelf Circulation Model: Intrusion of Atlantic Water on the West Spitsbergen Shelf, Journal of Physical Oceanography, 46, 1209-1230, https://doi.org/10.1175/JPO-D-15-0058.1, 2016.

Pachauri, R. K. and Meyer, L. A., eds.: IPCC, 2014: Climate Change 2014: Synthesis Report. Contribution of Working Groups I, II and III to the Fifth Assessment Report of the Intergovernmental Panel on Climate Change, IPCC, Geneva, Switzerland, 151 pp, 2014.

Pawlowicz, R., B., B., and Lentz, S.: Classical Tidal Harmonic Analysis Including Error Estimates in MATLAB using ttide, Computers and Geosciences, 28, 929-937, 2002.

Platt, S. M., Eckhardt, S., Ferré, B., Fisher, R. E., Hermansen, O., Jansson, P., Lowry, D., Nisbet, E. G., Pisso, I., Schmidbauer, N., Silyakova, A., Stohl, A., Svendby, T. M., Vadakkepuliyambatta, S., Mienert, J., and Lund Myhre, C.: Methane at Svalbard and over the European Arctic Ocean, Atmospheric Chemistry and Physics, 18, 17 207-17 224, https://doi.org/10.5194/acp-18-17207-2018, 2018.

Portnov, A., Vadakkepuliyambatta, S., Mienert, J., and Hubbard, A.: Ice-sheet-driven methane storage and release in the Arctic, Nature Communications, 7, 10314, https://doi.org/10.1038/ncomms 10314, 2016.

Rajan, A., Mienert, J., and Bünz, S.: Acoustic evidence for a gas migration and release system in Arctic glaciated continental margins offshore NW-Svalbard, Marine and Petroleum Geology, 32, 36-49, https://doi.org/https://doi.org/10.1016/j.marpetgeo.2011.12.008, 2012.

Reagan, M. T., Moridis, G. J., Elliott, S. M., and Maltrud, M.: Contribution of oceanic gas hydrate dissociation to the formation of Arctic Ocean methane plumes, Journal of Geophysical Research: Oceans, 116, https://doi.org/https://doi.org/10.1029/2011JC007189, 2011.

Reeburgh, W. S.: Oceanic Methane Biogeochemistry, Chemical Reviews, 107, 486-513, https://doi.org/10.1021/cr050362v, 2007.

Römer, M., Riedel, M., Scherwath, M., Heesemann, M., and Spence, G. D.: Tidally controlled gas bubble emissions: A comprehensive study using long-term monitoring data from the NEPTUNE cabled observatory offshore Vancouver Island, Geochemistry, Geophysics, Geosystems, 17, 3797-3814, https://doi.org/10.1002/2016GC006528, 2016.

Ruppel, C. and Kessler, J.: The interaction of climate change and methane hydrates, Reviews of Geophysics, 55, 126-168, https://doi.org/10.1002/2016RG000534, 2017.

Sahling, H., Römer, M., Pape, T., Bergès, B., dos Santos Fereirra, C., Boelmann, J., Geprägs, P., Tomczyk, M., Nowald, N., Dimmler, W., Schroedter, L., Glockzin, M., and Bohrmann, G.: Gas emissions at the continental margin west of Svalbard: mapping, sampling, and quantification, Biogeosciences, 11, 6029-6046, https://doi.org/10.5194/bg-11-6029-2014, 2014.

Saloranta, T. M. and Svendsen, H.: Across the Arctic front west of Spitsbergen: high-resolution CTD sections from 1998-2000, Polar Research, 20, 177-184, https://doi.org/10.1111/j.1751-8369.2001.tb00054.x, 2001.

Sarkar, S., Berndt, C., Minshull, T. A., Westbrook, G. K., Klaeschen, D., Masson, D. G., Chabert, A., and Thatcher, K. E.: Seismic evidence for shallow gas-escape features associated with a retreating gas hydrate zone offshore west Svalbard, Journal of Geophysical Research: Solid Earth, 117, https://doi.org/10.1029/2011JB009126, 2012. 
https://doi.org/10.5194/os-2021-85

Preprint. Discussion started: 13 September 2021

(c) Author(s) 2021. CC BY 4.0 License.

Saunois, M., Jackson, R. B., Bousquet, P., Poulter, B., and Canadell, J. G.: The growing role of methane in anthropogenic climate change,

Environmental Research Letters, 11, 120 207, https://doi.org/10.1088/1748-9326/11/12/120207, 2016.

Saunois, M., R. Stavert, A., Poulter, B., Bousquet, P., G. Canadell, J., B. Jackson, R., A. Raymond, P., J. Dlugokencky, E., Houweling, S., K.

Patra, P., Ciais, P., K. Arora, V., Bastviken, D., Bergamaschi, P., R. Blake, D., Brailsford, G., Bruhwiler, L., M. Carlson, K., Carrol, M.,

Castaldi, S., Chandra, N., Crevoisier, C., M. Crill, P., Covey, K., L. Curry, C., Etiope, G., Frankenberg, C., Gedney, N., I. Hegglin, M., Höglund-Isaksson, L., Hugelius, G., Ishizawa, M., Ito, A., Janssens-Maenhout, G., M. Jensen, K., Joos, F., Kleinen, T., B. Krummel, P., L. Langenfelds, R., G. Laruelle, G., Liu, L., MacHida, T., Maksyutov, S., C. McDonald, K., McNorton, J., A. Miller, P., R. Melton, J., Morino, I., Müller, J., Murguia-Flores, F., Naik, V., Niwa, Y., Noce, S., O’Doherty, S., J. Parker, R., Peng, C., Peng, S., P. Peters, G., Prigent, C., Prinn, R., Ramonet, M., Regnier, P., J. Riley, W., A. Rosentreter, J., Segers, A., J. Simpson, I., Shi, H., J. Smith, S., Paul Steele, L., F. Thornton, B., Tian, H., Tohjima, Y., N. Tubiello, F., Tsuruta, A., Viovy, N., Voulgarakis, A., S. Weber, T., Van Weele, M., R. Van Der Werf, G., F. Weiss, R., Worthy, D., Wunch, D., Yin, Y., Yoshida, Y., Zhang, W., Zhang, Z., Zhao, Y., Zheng, B., Zhu, Q., Zhu, Q., and Zhuang, Q.: The global methane budget 2000-2017, Earth System Science Data, 12, 1561-1623, https://doi.org/10.5194/essd-12-1561-2020, 2020.

Schlüter, M., Linke, P., and Suess, E.: Geochemistry of a sealed deep-sea borehole on the Cascadia Margin, Marine Geology, 148, 9-20, https://doi.org/https://doi.org/10.1016/S0025-3227(98)00016-4, 1998.

Shakhova, N., Semiletov, I., Leifer, I., Salyuk, A., Rekant, P., and Kosmach, D.: Geochemical and geophysical evidence of methane release over the East Siberian Arctic Shelf, Journal of Geophysical Research: Oceans, 115, https://doi.org/10.1029/2009JC005602, 2010.

Silyakova, A., Jansson, P., Serov, P., Ferré, B., Pavlov, A. K., Hattermann, T., Graves, C. A., Platt, S. M., Myhre, C. L., Gründger, F., and Niemann, H.: Physical controls of dynamics of methane venting from a shallow seep area west of Svalbard, Continental Shelf Research, 194, 104 030, https://doi.org/https://doi.org/10.1016/j.csr.2019.104030, 2020.

Sloan, E. D.: Physical/chemical properties of gas hydrates and application to world margin stability and climatic change, Geological Society, London, Special Publications, 137, 31-50, 1998.

Sommer, S., Schmidt, M., and Linke, P.: Continuous inline mapping of a dissolved methane plume at a blowout site in the Central North Sea UK using a membrane inlet mass spectrometer - Water column stratification impedes immediate methane release into the atmosphere, Marine and Petroleum Geology, 68, 766-775, https://doi.org/10.1016/j.marpetgeo.2015.08.020, 2015.

Steinle, L., Graves, C., Treude, T., Ferre, B., Biastoch, A., Bussmann, I., Berndt, C., Krastel, S., James, R., Behrens, E., Böning, C., Greinert, J., Sapart, C., Scheinert, M., Sommer, S., Lehmann, M., and Niemann, H.: Water column methanotrophy controlled by a rapid oceanographic switch, Nature Geoscience, 8, 378-382, https://doi.org/10.1038/NGEO2420, 2015.

Tverberg, V., Nøst, O. A., Lydersen, C., and Kovacs, K. M.: Winter sea ice melting in the Atlantic Water subduction area, Svalbard Norway, Journal of Geophysical Research: Oceans, 119, 5945-5967, https://doi.org/10.1002/2014JC010013, 2014.

Veloso, M., Greinert, J., Mienert, J., and Batist, M.: A new methodology for quantifying bubble flow rates in deep water using splitbeam echosounders: Examples from the Arctic offshore NW-Svalbard, Limnology and Oceanography: Methods, 13, 267-287, 2015.

Veloso-Alarcón, M. E., Jansson, P., Batist, M. D., Minshull, T. A., Westbrook, G. K., Pälike, H., Bünz, S., Wright, I., and Greinert, J.: Variability of Acoustically Evidenced Methane Bubble Emissions Offshore Western Svalbard, Geophysical Research Letters, 46, 90729081, https://doi.org/10.1029/2019GL082750, 2019.

von Appen, W.-J., Schauer, U., Hattermann, T., and Beszczynska-Möller, A.: Seasonal Cycle of Mesoscale Instability of the West Spitsbergen Current, Journal of Physical Oceanography, 46, 1231-1254, https://doi.org/10.1175/JPO-D-15-0184.1, 2016.

Westbrook, G. K., Thatcher, K. E., Rohling, E. J., Piotrowski, A. M., Pälike, H., Osborne, A. H., Nisbet, E. G., Minshull, T. A., Lanoisellé, M., James, R. H., Hühnerbach, V., Green, D., Fisher, R. E., Crocker, A. J., Chabert, A., Bolton, C., Beszczynska-Möller, A., Berndt, C., 
https://doi.org/10.5194/os-2021-85

Preprint. Discussion started: 13 September 2021

(C) Author(s) 2021. CC BY 4.0 License.

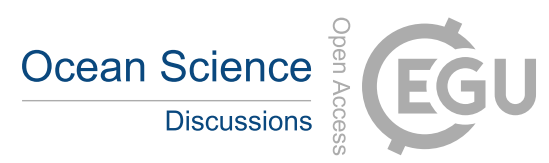

and Aquilina, A.: Escape of methane gas from the seabed along the West Spitsbergen continental margin, Geophysical Research Letters,

36, https://doi.org/10.1029/2009GL039191, 2009. 